Hydrothermal Alteration in

Research Drill Hole Y-3,

Lower Geyser Basin,

Yellowstone National Park,

Wyoming

U.S. GEOLOGICAL SURVEY PROFESSIONAL PAPER 1054-C

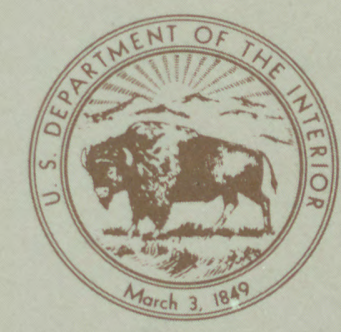





\section{Hydrothermal Alteration in Research Drill Hole Y-3, Lower Geyser Basin, Yellowstone National Park, Wyoming}

By KEITH E. BARGAR and MELVIN H. BEESON

HYDROTHERMAL STUDIES IN YELLOWSTONE NATIONAL PARK, WYOMING

U.S. GEOLOGICAL SURVEY PROFESSIONAL PAPER 1054-C

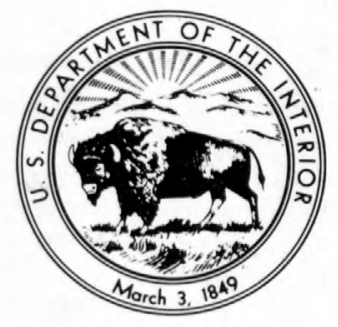

UNITED STATES GOVERNMENT PRINTING OFFICE, WASHINGTON : 1985 


\section{DEPARTMENT OF THE INTERIOR \\ DONALD PAUL HODEL, Secretary}

\section{U.S. GEOLOGICAL SURVEY}

Dallas L. Peck, Director

Library of Congress Cataloging-in-Publication Data

Bargar, Keith E.

Hydrothermal alteration in research drill-hole Y-3, Lower Geyser Basin, Yellowstone National Park, Wyoming

(U.S. Geological Survey Professional Paper 1054-C)

Bibliography

Supt. of Docs. No.: I 19.16:1054-C

1. Hydrothermal deposits-Wyoming-Lower Geyser Basin. 2. Hydrothermal deposits-Yellowstone National Park. 3. BoringsWyoming-Yellowstone National Park. 5. Yellowstone National Park. I. Beeson, Melvin H. II. Title. III. Series: United States. Geological Survey. Professional Paper 1054-C 


\section{CONTENTS}

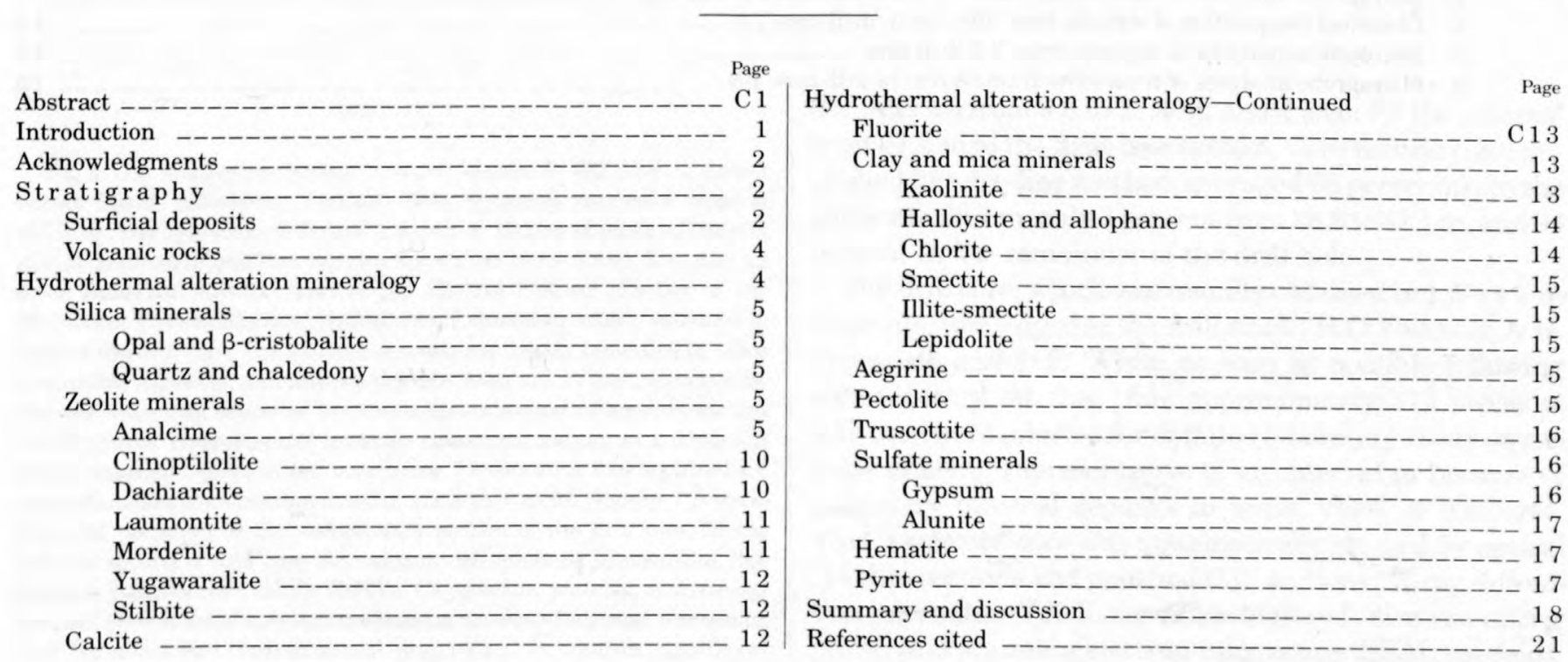

\section{ILLUSTRATIONS}

FIGURE 1. Map of Lower Geyser Basin showing locations of Y-3 and other research drill holes

2. Plot showing depth distribution of unaltered obsidian, $\alpha$-cristobalite, and hydrothermal alteration minerals from drill core Y-3

3. Scanning electron micrograph of euhedral, trapezohedral analcime crystals

4. Scanning electron micrograph of intergrown tabular clinoptilolite crystals ------------------------------ 5

5. Ca-Na-K tera

5. Ca-Na-K ternary diagram for heulandite-group zeolites from Yellowstone drill cores

6. Scanning electron micrograph of a large radiating cluster of dachiardite crystals

7. Scanning electron micrograph of cavity filling -----------------------------------------------11

8. Ca-Na-K ternary diagram for Y-3 dachiardite compared with other published dachiardite analyses

9. Scanning electron micrograph of laumontite crystals

10. Scanning electron micrograph of fibrous mordenite crystals

11. Ca-Na-K ternary diagram for microprobe chemical analyses of mordenite

12-15. Scanning electron micrographs of:

12. Euhedral crystals of yugawaralite -------------------------------------------------13

13. Blocky stilbite(?) crystals --------------------------------------------------13

14. A polycrystalline mat of lepidolite crystals

15. Clusters of aegirine crystals -------------------------------------------------16

16. $\mathrm{Ac}-\mathrm{Jd}-\mathrm{Di}+\mathrm{Hd}$ ternary diagram for aegirine -------------------------------------------------16

17. Scanning electron micrographs of fibrous and bladed pectolite

18. Scanning electron micrograph of tabular, hexagonal crystals of truscottite

19. $\mathrm{CaO}-\mathrm{Al}_{2} \mathrm{O}_{3}-\mathrm{SiO}_{2}$ molecular-proportion ternary diagram for truscottite --------------------------------18

20. Scanning electron micrograph of pyrite needlelike crystals

21. Generalized paragenetic sequence of principal hydrothermal minerals in drill core Y-3

22. A-F-M and $\mathrm{Na}_{2} \mathrm{O}-\mathrm{K}_{2} \mathrm{O}-\mathrm{CaO}$ ternary diagrams for altered volcanic rocks and glacial sediments from drill core $\mathrm{Y}-3$ - ------ 21

23. Plot of fluid-inclusion homogenization temperatures in quartz and fluorite crystals from drill core Y-3 


\section{TABLES}

TABLE 1. Chemical composition, $\mathrm{pH}$, temperature, and calculated geothermometers of thermal water from Y-3 drill hole compared with values from nearby Ojo Caliente Hot Spring

2. Chemical composition of some zeolite minerals from Y-3 drill core

3. Microprobe analyses of dachiardite from Y-3 drill core

4. Chemical composition of chlorite from $108.3 \mathrm{~m}$ in drill core Y-3 ---------------------------------------14

5. Microprobe analyses of aegirine from Y-3 drill core - - - - - - - - - - - - - - - - - - - - - - - - - - - - - - - - - - - - 17

6. Microprobe analyses of truscottite from $88.6 \mathrm{~m}$ in drill core $\mathrm{Y}-3$ 


\title{
HYDROTHERMAL ALTERATION IN RESEARCH DRILL HOLE Y-3, LOWER GEYSER BASIN, YELLOWSTONE NATIONAL PARK, WYOMING
}

\author{
By Keith E. Bargar and Melvin H. Beeson
}

\section{ABSTRACT}

Y-3, a U.S. Geological Survey research diamond- drill hole in Lower Geyser Basin, Yellowstone National Park, Wyoming, reached a depth of $156.7 \mathrm{~m}$. The recovered drill core consists of $42.2 \mathrm{~m}$ of surficial (mostly glacial) sediments and two rhyolite flows (Nez Perce Creek flow and an older, unnamed rhyolite flow) of the Central Plateau Member of the Pleistocene Plateau Rhyolite. Hydrothermal alteration is fairly extensive in most of the drill core. The surficial deposits are largely cemented by silica and zeolite minerals; and the two rhyolite flows are, in part, bleached by thermal water that deposited numerous hydrothermal minerals in cavities and fractures. Hydrothermal minerals containing sodium as a dominant cation (analcime, clinoptilolite, mordenite, Na-smectite, and aegirine) are more abundant than calcium-bearing minerals (calcite, fluorite, Ca-smectite, and pectolite) in the sedimentary section of the drill core. In the volcanic section of drill core Y-3, calcium-rich minerals (dachiardite, laumontite, yugawaralite, calcite, fluorite, Ca-smectite, pectolite, and truscottite) are predominant over sodium-bearing minerals (aegirine, mordenite, and Na-smectite). Hydrothermal minerals that contain significant amounts of potassium (alunite and lepidolite in the sediments and illitesmectite in the rhyolite flows) are found in the two drill-core intervals. Drill core Y-3 also contains hydrothermal silica minerals (opal, $\beta$-cristobalite, chalcedony, and quartz), other clay minerals (allophane, halloysite, kaolinite, and chlorite), gypsum, pyrite, and hematite. The dominance of calcium-bearing hydrothermal minerals in the lower rhyolitic section of the Y-3 drill core appears to be due to loss of calcium, along with potassium, during adiabatic cooling of an ascending boiling water.

\section{INTRODUCTION}

Research diamond-drill hole Y-3 is one of 13 holes completed by the U.S. Geological Survey at selected sites in hot-spring and geyser areas of Yellowstone National Park (fig. 1). The holes were drilled in 1967 and 1968 in order to obtain detailed physical and chemical data on the shallow part of a high-temperature geothermal system (White and others, 1975). Drill hole Y-3 is located at the western margin of the Pocket Basin hydrothermal explosion crater debris ridge (Muffler and others, 1971). The drill-hole surface occurs at an elevation of $\sim 2,193 \mathrm{~m}$; Y-3 is about $76 \mathrm{~m}$ north of and $2 \mathrm{~m}$ higher than Ojo Caliente Hot Spring, a major thermal feature in the area (White and others, 1975).

Drilling of Y-3 (using water as the circulating fluid) began on June 8, 1967, and was terminated on June 28, 1967, after reaching a depth of $156.7 \mathrm{~m}$. The drill hole was later plugged with cement in 1969 . The core diameter is $10.2 \mathrm{~cm}$ for the interval from the surface to $9.8 \mathrm{~m}, 6.0 \mathrm{~cm}$ for the interval from 9.8 to $27.4 \mathrm{~m}$, and $4.4 \mathrm{~cm}$ for the interval from $27.4 \mathrm{~m}$ to the drill-hole bottom. Core recovery, accomplished by wire-line method, averaged 65 percent from the surface to $28.7 \mathrm{~m}$, only 3 percent from 28.5 to $41.1 \mathrm{~m}$, and 94 percent in the remainder of the drill hole.

The drill core, which was usually obtained in 1.5- or 3-m intervals, was logged at the drill site by R.O. Fournier, A.H. Truesdell, and D.E. White as soon as possible following core recovery. At that time approximately 370 pieces of drill core were selected for detailed laboratory study on the basis of being representative of an interval or because of secondary mineral deposits in veins, vugs, or fractures. This "skeleton" core was systematically studied by optical (44 thin sections and polished thin sections), X-ray diffraction (more than $700 \mathrm{X}$-ray diffractograms), electron microprobe, and scanning electron microscope (SEM) methods. Whole-rock chemical analyses by rapid rock methods and semiquantitative spectrographic analyses for 16 selected Y-3 core samples are reported in Beeson and Bargar (1984). Bulk-rock and powdered-rock density measurements were also obtained for these 16 core samples. Two of the more abundant hydrothermal minerals (chlorite and laumontite) were concentrated by heavy liquids for conventional rock analysis.

Physical data for the 13 Yellowstone research drill holes are reported in White and others (1975). The highest temperature recorded in Y-3 was $196.0{ }^{\circ} \mathrm{C}$ at a depth of $\sim 150.6 \mathrm{~m}$ (fig. 2), and the maximum near-bottom fluid pressure was $\sim 1,497 \mathrm{kPa}$.

Bargar and others (1973) indicate that the Y-3 drill hole encountered at least two major water-producing zones at depths of 28 and $88 \mathrm{~m}$, and they provide a chemical analysis of the slightly alkaline water from the 88-m aquifer (table 1, column 2). More recently a chemical analysis of water from the bottom of the Y-3 drill hole was reported by Keith and others (1983), and the analysis is reproduced here in table 1 , column 1 . This water is slightly more concentrated in the major constituents $\left(\mathrm{Na}, \mathrm{HCO}_{3}\right.$, and $\mathrm{Cl}$ ) than water from the $88-\mathrm{m}$ aquifer. Silica was not reported in either of the two analyses; however, $\mathrm{SiO}_{2}$ (along with $\mathrm{Na}, \mathrm{HCO}_{3}$, and $\mathrm{Cl}$ ) is one of the four main components of nearby Ojo Caliente Hot Spring water (table 1, column 3) (Thompson and Yadav, 1979). 


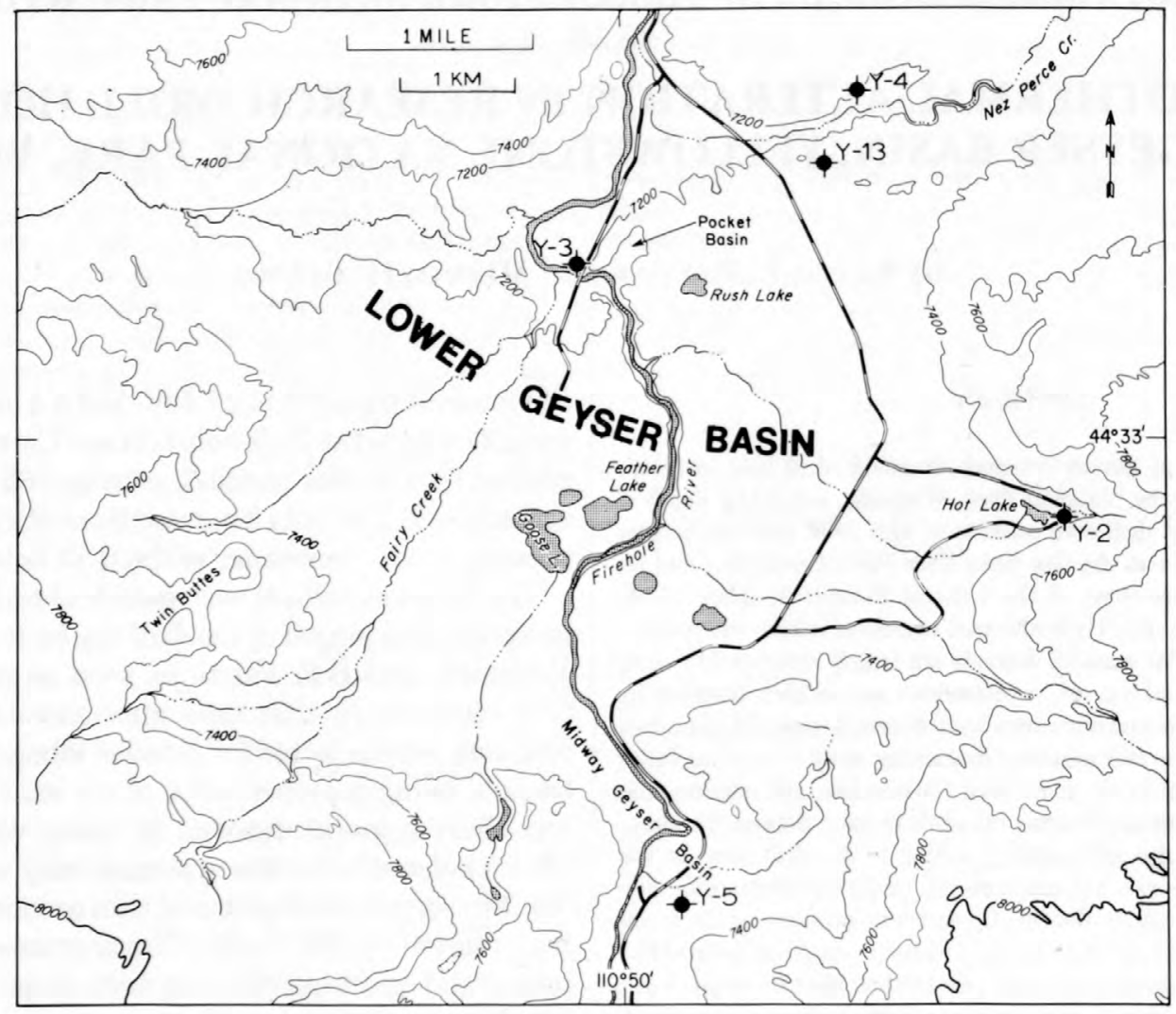

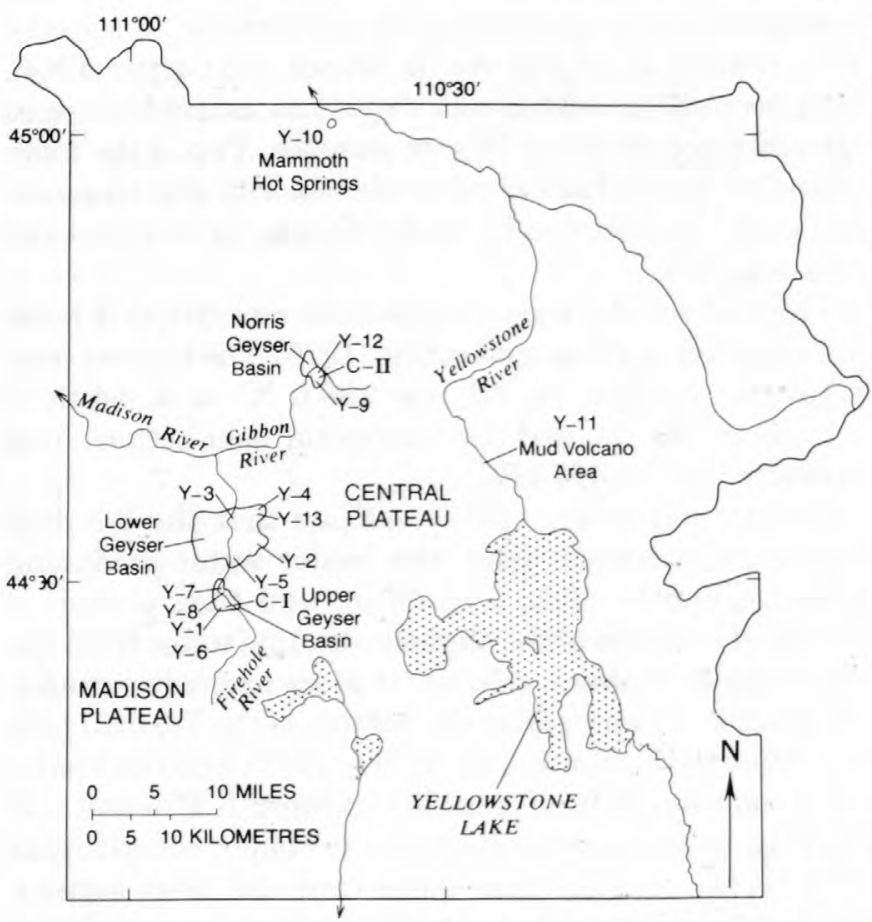

Figure 1.-Map of Lower Geyser Basin showing locations of Y-3 and other research drill holes. Index map of Yellowstone National Park shows the locations of Lower Geyser Basin, drill holes Y-1 through Y-13 drilled by U.S. Geological Survey in 1967 and 1968, and drill holes C-I and C-II drilled by the Carnegie Institution of Washington in 1929 (Fenner, 1936).

\section{ACKNOWLEDGMENTS}

The authors would like to thank T.E.C. Keith and D.E. White for their critical reviews and helpful discussion of the manuscript. R.L. Oscarson assisted in obtaining SEM micrographs, and L.J.P. Muffler provided us with his notes on the petrography of some of the Y-3 drill core.

\section{STRATIGRAPHY SURFICIAL DEPOSITS}

The upper $1.6 \mathrm{~m}$ of Y-3 drill core consists of buff-towhite clayey (smectite and kaolinite) alluvial soil that contains some sand-sized grains of black spherical obsidian and clear botryoidal opal and angular-to-subrounded light-gray rhyolite pebbles.

Between 1.6 and $42.2 \mathrm{~m}$ the drill core is composed of red, brown, gray, or green hydrothermally cemented siltstone, sandstone, and conglomerate. The massive to thinly bedded sediments have dips that range from horizontal (perpendicular to drill core that is presumed to be vertical) to about $30^{\circ}$; several samples display crossbedding or contorted bedding. The conglomeratic material is poorly sorted and contains mostly rhyolite and obsidian clasts, although a few samples have sandstone pebbles. These sediments were deposited during the Pinedale glacial episode $(\geqslant 45,000-14,000$ years B.P.) 


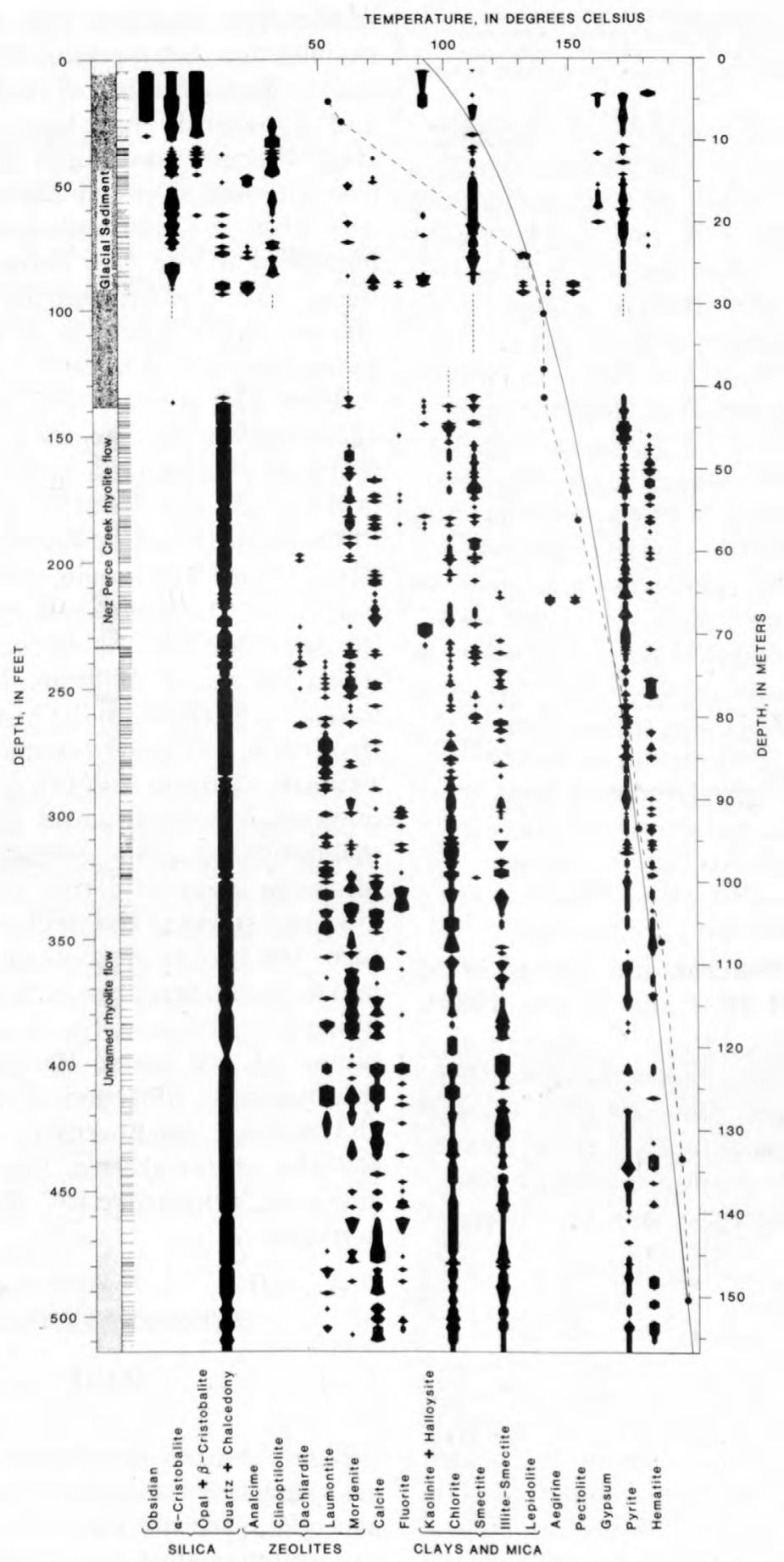

FigURE 2.-Plot showing depth distribution of unaltered obsidian, $\alpha$-cristobalite, and hydrothermal alteration minerals from drill core Y-3. Left column shows a generalized stratigraphic section of rock units penetrated by the drill hole. The unnamed rhyolite flow and the Nez Perce Creek rhyolite flow are included in the Central Plateau Member of the Plateau Rhyolite. Horizontal lines adjacent to left column represent distribution of samples studied. Only a few core fragments and drill cuttings were recovered between 28.5 and $41.1 \mathrm{~m}$, and the distribution of hydrothermal minerals in the interval, as suggested by these few samples, is shown by vertical dotted lines. Width of mineral columns given as an estimate of relative abundance based on X-ray diffraction analyses and microscopic observations. Vertical continuity in mineral presence between samples is assumed except where a mineral abundance becomes zero, in which case the zero point is arbitrarily placed $0.3 \mathrm{~m}$ from the last occurrence of the mineral. Dashed curve connects bottom-hole temperature measurements obtained as drilling progressed. Solid curve shows reference boiling temperature for pure water assuming a surface altitude of $\sim 2,329 \mathrm{~m}$ and a water table at the surface. Temperature data from White and others (1975). 


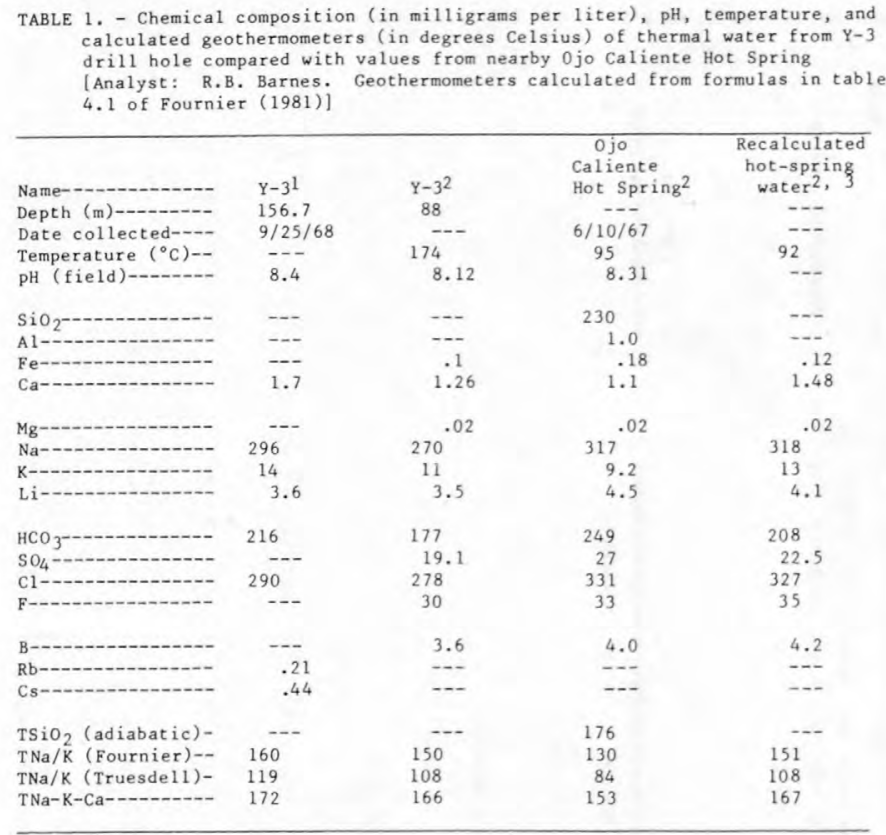

$1_{\text {Keith }}$ and others (1983). Ca value from original unpublished analysis by R.B. Barnes.

Bargar and others (1973), Fournier (1981).

${ }^{3}$ Calculated, ideal composition of 0 jo Caliente Hot Spring water from column 2 assuming no wallrock reaction or precipitation of dissolved constituents.

(Muffler and others, 1971; Waldrop and Pierce, 1975; Pierce and others, 1976; Muffler and others, 1982). Hydrothermal alteration is extensive in samples recovered throughout most of the interval, and hydrothermal minerals include opal, $\beta$-cristobalite, quartz, chalcedony, analcime, clinoptilolite, mordenite, calcite, fluorite, allophane, halloysite, kaolinite, chlorite, smectite, lepidolite, aegirine, pectolite, gypsum, alunite, pyrite, and hematite.

\section{VOLCANIC ROCKS}

From 42.2 to $71.2 \mathrm{~m}$ the drill core penetrated the $\mathrm{Nez}$ Perce Creek rhyolite flow of the Central Plateau Member of the Pleistocene Plateau Rhyolite (Christiansen and Blank, 1974), which was extruded about 150,000 years ago (Waldrop and Pierce, 1975; White and others, 1975; Leeman and Phelps, 1981). Core samples from the Nez Perce Creek flow frequently consist of bleached rhyolite flow or flow breccia that is extensively fractured and in some places is quite vesicular. Predominant magmatic minerals are quartz and sanidine; pyroxene, plagioclase, and magnetite are minor constituents. Evidence for vapor-phase mineralization is sparse, although a few cavities contain hydrothermal quartz druses that appear to be pseudomorphous after vaporphase alkali feldspar crystals. Spherulitic or micro- spherulitic textures are common throughout the rhyolite flow, but $\alpha$-cristobalite, which frequently forms due to devitrification of cooling rhyolite flows, is rare and apparently has been recrystallized to quartz. Hydrothermal quartz and chalcedony are abundant on fractures and as vesicle fillings throughout much of this core interval. Other open-space hydrothermal minerals identified in the Nez Perce Creek flow include mordenite, dachiardite, aegirine, pectolite, calcite, fluorite, smectite, illite-smectite, chlorite, kaolinite, hematite, pyrite, and a $10-\AA$ mica(?).

Below $71.2 \mathrm{~m}$ is an older, unnamed rhyolite flow that apparently is not exposed anywhere at the surface within the Yellowstone Caldera. This flow is also correlated with the Central Plateau Member of the Pleistocene Plateau Rhyolite by Christiansen and Blank (1974). The unnamed rhyolite flow is probably not much older than the Nez Perce Creek flow because all of the lava flows of the Central Plateau Member were extruded about 200,000-70,000 years ago (Christiansen and Blank, 1972). In drill core Y-3, this unnamed rhyolite flow displays conspicuous flow banding and vesicularity. Quartz and sanidine are the most abundant magmatic minerals, and pyroxene, plagioclase, and magnetite are minor primary constituents. No vaporphase or devitrification minerals were identified, although parts of the drill core have a spherulitic texture. The core is extensively fractured, and hydrothermal minerals are quite abundant as vesicle and fracture fillings, to the extent that many of the fractures are completely self-sealed. Hydrothermal minerals found in this partially bleached rhyolite flow include quartz, chalcedony, dachiardite, laumontite, mordenite, stilbite, yugawaralite, truscottite, calcite, fluorite, smectite, illite-smectite, illite, chlorite, pyrite, and hematite.

\section{HYDROTHERMAL ALTERATION}

\section{MINERALOGY}

Figure 2 shows the distribution of unaltered obsidian, devitrification $\alpha$-cristobalite, and hydrothermal minerals (opal, $\beta$-cristobalite, quartz, chalcedony, analcime, clinoptilolite, dachiardite, laumontite, mordenite, calcite, fluorite, kaolinite, halloysite, chlorite, smectite, illite-smectite, lepidolite, aegirine, pectolite, gypsum, pyrite, and hematite) with depth in the Y-3 drill core. Vapor-phase, magmatic, and a few hydrothermal minerals with only minor distribution in the drill core (stilbite, yugawaralite, allophane, truscottite, and alunite) are not shown in the figure.

The only unaltered obsidian occurs in the coarsegrained sediments of the upper $10 \mathrm{~m}$ of the drill core. 
Below that depth, clastic obsidian grains are altered to clinoptilolite and smectite.

\section{SILICA MINERALS}

OPAL AND $\beta$-CRISTOBALITE

Sediments in the upper $14.0 \mathrm{~m}$ of the drill core are mostly cemented by clear-to-grayish opal. Opal also occurs in a few veins and vugs where the mineral usually has a botryoidal habit; however, one cavity at $4.7 \mathrm{~m}$ is partly filled by brown banded opal that grades upward to clear hyalite. X-ray diffraction analyses of two samples at 10.8 and $18.9 \mathrm{~m}$ show the presence of $\beta$ cristobalite associated with opal cement in the shallower deposit and a chalcedony vein in the deeper sample.

\section{QUARTZ AND CHALCEDONY}

Red-to-brown, green, and white-to-clear chalcedony occurs throughout most of the Y-3 drill core below $18.9 \mathrm{~m}$. The cryptocrystalline silica was deposited as botryoidal, irregular-to-massive, or horizontally layered cavity and fracture fillings. In addition, chalcedony forms the cementing material for a few pieces of conglomerate or brecciated drill core. It also appears to be the earliest hydrothermal mineral deposited in the Y-3 drill core, although some early chalcedony contains disseminated, minute pyrite crystals. A few chalcedony cavity fillings display microscopic convoluted bedding. Similar sedimentary structures in chalcedony cavity and fracture fillings of drill core Y-5 were interpreted by Keith and Muffler (1978) as being deposits of amorphous silica floc (opal) that later recrystallized to chalcedony.

Tiny (usually less than about $3 \mathrm{~mm}$ ), clear quartz crystals are sparse to absent above $41.8 \mathrm{~m}$, but the radiating crystal clusters are deposited in cavities and on fractures throughout most of the remainder of the drill core. Crystalline quartz appears to be an early hydrothermal mineral and probably was deposited shortly after the deposition of chalcedony. However, at $53.8 \mathrm{~m}$, quartz was deposited as more than one generation, and the paragenetic sequence is chalcedony, pyrite, hematite, quartz, calcite-?-fluorite, later quartz, and mordenite. Quartz and chalcedony can be found associated with most of the hydrothermal minerals except for clinoptilolite in the Y-3 drill core. A fairly close association is found between analcime and quartz or chalcedony zones, which alternate with clinoptilolite- $\alpha$ cristobalite zones in the upper $30 \mathrm{~m}$ of the drill core (fig. 2). This silica-zeolite relationship previously has been described for drill cores Y-1 and Y-8 (Honda and Muffler, 1970; Keith and others, 1978b), where the deposits are more extensive and the relationship is better defined.

\section{ZEOLITE MINERALS}

ANALCIME

Tiny $(0.025-0.5 \mathrm{~mm})$, isotropic, euhedral, trapezohedral analcime crystals (fig. 3) occur in the groundmass and as vesicle fillings in the Y-3 drill core from 14.2 to $15.3 \mathrm{~m}, 22.8$ to $24.1 \mathrm{~m}$, and 27.2 to $28.5 \mathrm{~m}$. Quartz is closely associated with analcime and appears to be pseudomorphous after groundmass analcime at $23.8 \mathrm{~m}$. Six electron microprobe chemical analyses of analcime from $27.5 \mathrm{~m}$ (table 2 ) show that the mineral is a pure analcime (sodium-rich) end member. The Y-3 analcime analyses have very high silica-to-alumina ratios (2.4-3.1) for analcime and are similar both to a microprobe analysis of analcime reported for drill core Y-8 (Keith and others, 1978b) and to conventional rock analyses of two analcime separates from drill core Y-1 (M.H. Beeson, unpub. data, 1976). Other Yellowstone drill cores that contain analcime are Y-2 and Y-13. In drill core Y-2 the mineral appears to be a sodium-rich wairakite (Bargar and Beeson, 1981), and in drill core Y-13 both analcime and wairakite appear to be present in the same sample (Bargar and others, 1981). Drill cores Y-1 and Y-8 mostly contain Na- and K-rich hydrothermal minerals and do not contain Ca-rich minerals (except for local bladed calcite) (Honda and Muffler, 1970; Keith and others, 1978b). Conversely, drill cores Y-2 and Y-13 contain several Ca-rich hydrothermal minerals (Keith and others, 1978a; Bargar and Beeson, 1981).

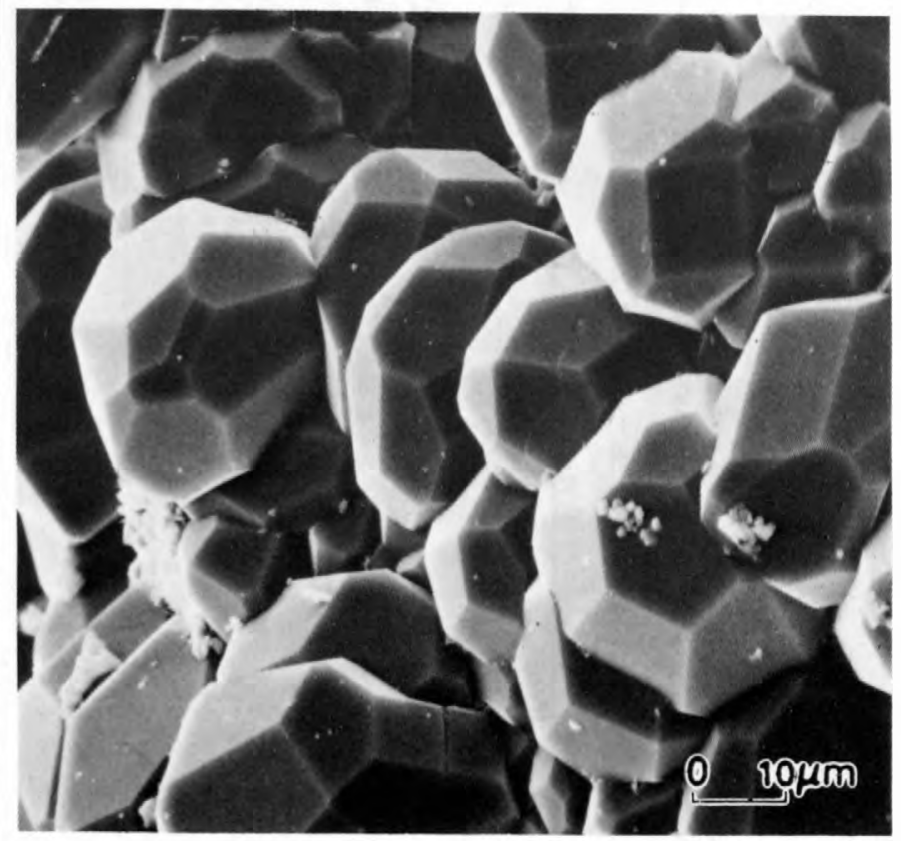

FiguRE 3.-Scanning electron micrograph of euhedral, trapezohedral analcime crystals from $28.3 \mathrm{~m}$ in drill hole Y-3. A few scattered clusters of smectite crystals are later deposits (after Bargar and others, 1981). 
TABLE 2. - Chemical composition of some zeolite minerals from $Y-3$ drill core

[All analyses except for laumontite (No. 5) and $\mathrm{H}_{2} \mathrm{O}^{+}$and $\mathrm{H}_{2} \mathrm{O}^{-}$of mordenite were determined by electron microprobe]

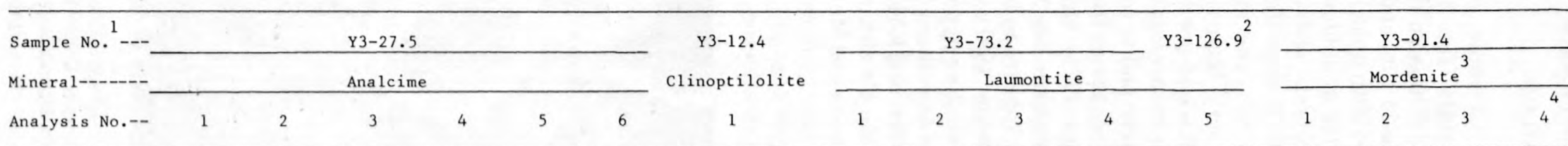

Weight percent

\begin{tabular}{|c|c|c|c|c|c|c|c|c|c|c|c|c|c|c|c|c|}
\hline $\mathrm{SiO}_{2}$ & 62.64 & 60.76 & 57.74 & 58.14 & 60.01 & 62.73 & 59.48 & 50.83 & 54.49 & 53.72 & 54.05 & 53.74 & 65.88 & 66.64 & 65.52 & 65.58 \\
\hline $\mathrm{Al}_{2} \mathrm{O}_{3}$ & 17.22 & 18.18 & 20.32 & 20.65 & 17.08 & 17.22 & 12.21 & 19.69 & 19.90 & 20.67 & 20.49 & 21.51 & 11.36 & 11.46 & 11.97 & 11.84 \\
\hline $\mathrm{Fe}_{2} \mathrm{O}_{3}-$ & .28 & .26 & .09 & .11 & .28 & .34 & 1.00 & .03 & .00 & .00 & .00 & .10 & .00 & .00 & .00 & .00 \\
\hline MgO-------- & .01 & .01 & .00 & .00 & .00 & .00 & .09 & .00 & .04 & .02 & .01 & .11 & .00 & .00 & .00 & .03 \\
\hline MnO--------- & .02 & .00 & .00 & .00 & .03 & .05 & .10 & .02 & .00 & .01 & .00 & - & .05 & .00 & .01 & .00 \\
\hline $\mathrm{CaO}---1-$ & .01 & .02 & .04 & .02 & .08 & .01 & .48 & 9.89 & 10.21 & 10.32 & 10.48 & 11.42 & 3.08 & 3.04 & 3.26 & 3.07 \\
\hline $\mathrm{Na}_{2} \mathrm{O}-\cdots-$ & 9.71 & 10.61 & 12.13 & 12.35 & 9.41 & 9.98 & 3.03 & .39 & .41 & .61 & .73 & .31 & 2.90 & 2.61 & 2.63 & $2.9 y$ \\
\hline $\mathrm{K}_{2} \mathrm{O}-$ & .04 & .03 & .05 & .04 & .03 & .05 & 4.99 & .16 & .20 & .11 & .17 & .078 & .26 & .27 & .29 & $\cdot 3$ \\
\hline $\mathrm{H}_{2} \mathrm{O}^{+}--$ & -- & --- & --- & --- & --- & --- & -- & --- & --- & --- & --- & 11.42 & 9.10 & 9.10 & 9.10 & 9.10 \\
\hline $\mathrm{H}_{2} \mathrm{O}^{-}-\cdots$ & -- & -- & -- & --- & --- & --- & --- & --- & --- & --- & --- & 2.06 & 4.90 & 4.90 & 4.90 & 4.90 \\
\hline F-- & --- & --- & --- & --- & --- & --- & --- & -- & --- & --- & -- & $<.01$ & --- & --- & -- & $\cdots$ \\
\hline Total---- & 89.93 & 89.87 & 90.37 & 91.31 & 86.92 & 90.38 & 81.38 & 81.01 & 85.25 & 85.46 & 85.93 & 100.76 & 97.53 & 98.02 & 97.68 & 97.87 \\
\hline
\end{tabular}

Number of atoms on the basis of:

96 oxygens

72 oxygens

48 oxygens

96 oxygens

\begin{tabular}{|c|c|c|c|c|c|c|c|c|c|c|c|c|c|c|c|c|}
\hline 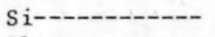 & 36.33 & 35.51 & 33.94 & 33.84 & 36.06 & 36.27 & 28.84 & 16.53 & 16.80 & 16.56 & 16.59 & 16.29 & 39.99 & 40.11 & 39.70 & 39.71 \\
\hline Al---------- & 11.77 & 12.52 & 14.08 & 14.17 & 12.09 & 11.73 & 6.98 & 7.55 & 7.23 & 7.51 & 7.41 & 7.68 & 8.13 & 8.13 & 8.55 & 8.45 \\
\hline Fe-------- & .12 & .11 & .04 & .05 & .13 & .15 & .36 & .01 & .00 & .00 & .00 & .02 & .00 & .00 & .00 & .00 \\
\hline 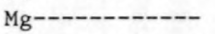 & .01 & .01 & .00 & .00 & .00 & .00 & .06 & .00 & .02 & .01 & .01 & .05 & .00 & .00 & .00 & .03 \\
\hline Mn--------- & .01 & .00 & .00 & .00 & .02 & .02 & .04 & .01 & .00 & .00 & .00 & --- & .03 & .00 & .00 & .00 \\
\hline Ca------------- & .01 & .01 & .03 & .01 & .05 & .00 & .25 & 3.45 & 3.37 & 3.41 & 3.45 & 3.71 & 2.01 & 1.96 & 2.12 & 1.99 \\
\hline 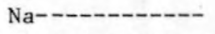 & 10.91 & 12.02 & 13.82 & 13.94 & 10.96 & 11.19 & 2.85 & .24 & .25 & .36 & .43 & .18 & 3.41 & 3.04 & 3.09 & 3.51 \\
\hline K--------- & .03 & .02 & .04 & .03 & .02 & .04 & 3.09 & .07 & .08 & .04 & .07 & .03 & .20 & .10 & .23 & .28 \\
\hline Si/Al-------- & 3.09 & 2.84 & 2.41 & 2.39 & 2.98 & 3.09 & 4.13 & 2.19 & 2.32 & 2.21 & 2.24 & 2.12 & 4.92 & 4.93 & 4.64 & 4.70 \\
\hline $\begin{array}{l}\text { Cat. bal. } \\
\text { error }(\%)^{5}\end{array}$ & 8.3 & 4.6 & 1.5 & 1.6 & 10.0 & 5.3 & 10.6 & 4.8 & 1.8 & 3.7 & .2 & -.3 & 5.9 & 15.1 & 13.1 & 7.9 \\
\hline
\end{tabular}




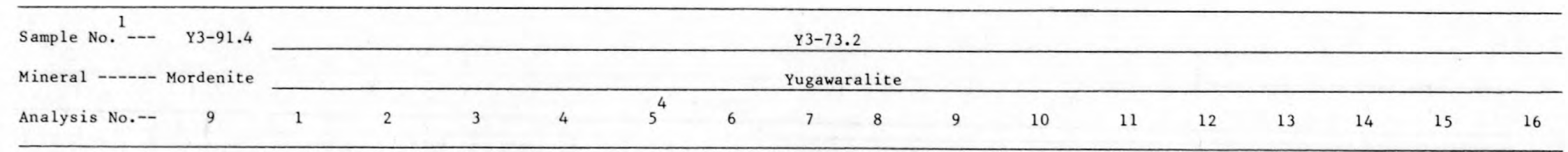

Weight percent

\begin{tabular}{|c|c|c|c|c|c|c|c|c|c|c|c|c|c|c|c|c|c|}
\hline $\mathrm{SiO}_{2} \cdots$ & 67.56 & 63.93 & 63.99 & 60.74 & 63.32 & 63.03 & 64.94 & 64.88 & 62.46 & 62.48 & 62.55 & 63.60 & 63.38 & 64.45 & 64.86 & 63.07 & 63.93 \\
\hline $\mathrm{Al}_{2} \mathrm{O}_{3} \cdots$ & 11.62 & 17.70 & 18.46 & 18.51 & 18.73 & 17.93 & 16.91 & 18.56 & 16.55 & 17.00 & 16.48 & 15.88 & 16.36 & 15.46 & 16.24 & 16.07 & 16.03 \\
\hline $\mathrm{Fe}_{2} \mathrm{O}_{3} \cdots$ & .00 & .00 & .00 & .00 & .00 & .00 & .00 & .00 & .01 & .03 & .00 & .00 & .02 & .04 & .00 & .03 & .02 \\
\hline $\mathrm{MgO}-$ & .00 & .00 & .00 & .00 & .01 & .01 & .01 & .00 & .03 & .01 & .03 & .02 & .02 & .01 & .04 & .00 & .03 \\
\hline MnO--:---- & .02 & .00 & .00 & .00 & .04 & .00 & .00 & .02 & .03 & .01 & .00 & .03 & .01 & .00 & .00 & .04 & .00 \\
\hline $\mathrm{CaO}--\cdot--$ & 3.18 & 9.04 & 8.97 & 9.21 & 8.95 & 9.06 & 8.01 & 9.90 & 8.92 & 9.33 & 9.00 & 8.78 & 8.97 & 8.41 & 8.16 & 8.64 & 8.68 \\
\hline $\mathrm{Na}_{2} \mathrm{O}-\cdots$ & 2.48 & .36 & .37 & .09 & .40 & .33 & .82 & .02 & .43 & .20 & .28 & .50 & .29 & .69 & .74 & .51 & .47 \\
\hline $\mathrm{K}_{2} \mathrm{O}-\cdots$ & .28 & .05 & .07 & .11 & .06 & .05 & .25 & .02 & .04 & .05 & .06 & .06 & .05 & .08 & .10 & .10 & .07 \\
\hline $\mathrm{H}_{2} \mathrm{O}^{+}$ & 9.10 & --- & --- & --- & --- & --- & --- & -- & --- & --- & --- & -- & -- & -- & -- & --- & --- \\
\hline $\begin{array}{l}\mathrm{H}_{2} \mathrm{O}^{-}- \\
\mathrm{F}\end{array}$ & 4.90 & --- & --- & --- & --- & --- & --- & --- & -- & --- & --- & --- & --- & --- & --- & --- & --- \\
\hline Tota1-- & 99.14 & 91.08 & 91.86 & 88.66 & 91.51 & 90.41 & 90.94 & 93.40 & 88.47 & 89.11 & 88.40 & 88.87 & 89.10 & 89.14 & 90.14 & 88.46 & 89.23 \\
\hline
\end{tabular}

Number of atoms on the basis of:

96 oxygens 56 oxygens

\begin{tabular}{|c|c|c|c|c|c|c|c|c|c|c|c|c|c|c|c|c|c|}
\hline 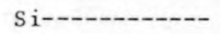 & 40.11 & 21.15 & 21.00 & 20.71 & 20.88 & 21.03 & 21.48 & 20.97 & 21.30 & 21.17 & 21.33 & 21.55 & 21.43 & 21.74 & 21.62 & 21.48 & 21.56 \\
\hline Al---1--1-- & 8.14 & 6.91 & 7.14 & 7.44 & 7.28 & 7.05 & 6.59 & 7.07 & 6.65 & 6.79 & 6.62 & 6.34 & 6.52 & 6.15 & 6.38 & 6.45 & 6.37 \\
\hline $\mathrm{Fe}^{----}$ & .00 & .00 & .00 & .00 & .00 & .00 & .00 & .00 & .00 & .01 & .00 & .00 & .01 & .01 & .00 & .01 & .01 \\
\hline 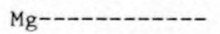 & .00 & .00 & .00 & .00 & .01 & .00 & .00 & .00 & .01 & .01 & .01 & .01 & .01 & .00 & .02 & .00 & .01 \\
\hline Mn---------- & .01 & .00 & .00 & .00 & .01 & .00 & .00 & .01 & .01 & .00 & .00 & .01 & .00 & .00 & .00 & .01 & .00 \\
\hline $\mathrm{Ca}$ & 2.02 & 3.21 & 3.16 & 3.37 & 3.16 & 3.24 & 2.84 & 3.43 & 3.26 & 3.39 & 3.29 & 3.19 & 3.25 & 3.04 & 2.92 & 3.15 & 3.14 \\
\hline $\mathrm{Na}$ & 2.85 & .23 & .24 & .06 & .25 & .21 & .53 & .01 & .28 & .13 & .19 & .33 & .19 & .45 & .48 & .34 & .31 \\
\hline 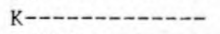 & .21 & .02 & .03 & .05 & .02 & .02 & .11 & .01 & .01 & .02 & .03 & .03 & .02 & .04 & .04 & .05 & .03 \\
\hline Si/Al-- & 4.93 & 3.06 & 2.94 & 2.78 & 2.87 & 2.98 & 3.26 & 2.97 & 3.20 & 3.12 & 3.22 & 3.40 & 3.29 & 3.54 & 3.39 & 3.33 & 3.38 \\
\hline $\begin{array}{l}\text { Cat. bal. } \\
\text { error }(\%)^{5}--\end{array}$ & 14.0 & 3.6 & 8.6 & 8.8 & 9.7 & 4.9 & 4.3 & 2.6 & -2.9 & -2.2 & -2.8 & -6.3 & -3.1 & -6.4 & -.4 & -3.8 & -4.0 \\
\hline
\end{tabular}

Sample numbers correspond to depth in meters.

${ }^{2}$ Analyzed by conventional rock-analysis methods. Analysts: S. T. Neil and J. H. Christie.

${ }_{3} \mathrm{H}_{2} \mathrm{O}^{+}$and $\mathrm{H}_{2} \mathrm{O}^{-}$determined by conventional rock-analysis method. Analyst: S. T. Neil.

${ }^{4}$ Average of five analyses.

${ }^{5}$ Determined by method of Passaglia (1970). 
TABLE 3. -- Microprobe analyses of dachiardite from $Y-3$ drill core

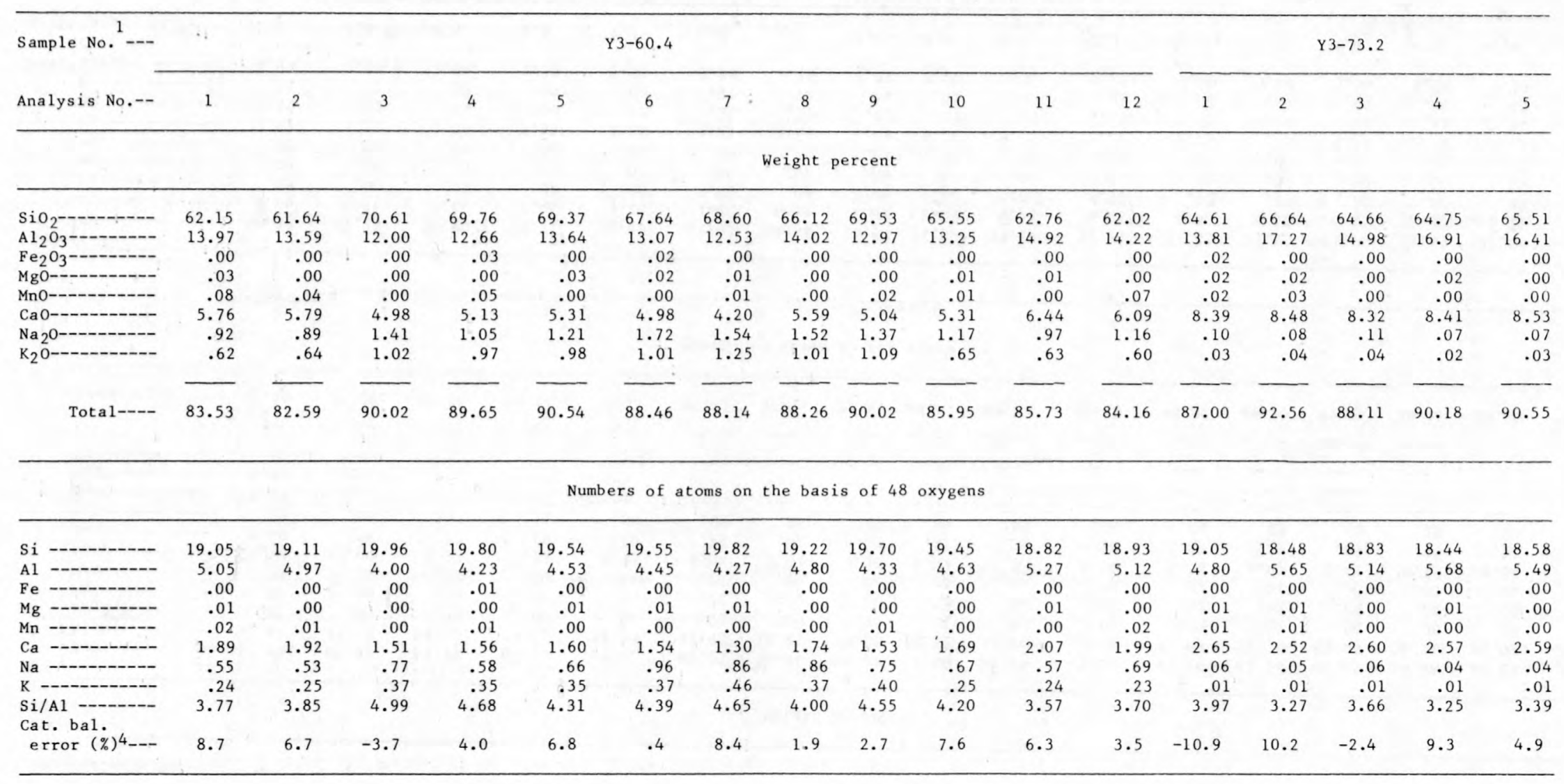




\begin{tabular}{|c|c|c|c|c|c|c|c|c|c|c|c|c|c|c|c|c|c|}
\hline Sample No. ${ }^{1}---$ & & & & & & & Y $3-7$ & & & & & & & & & & \\
\hline Analysis No.-- & 6 & 7 & 8 & 9 & $10^{2}$ & 11 & $: \quad 12$ & $13^{3}$ & 14 & 15 & 16 & 17 & 18 & 19 & 20 & 21 & 22 \\
\hline \multicolumn{18}{|c|}{ Weight percent } \\
\hline $\mathrm{SiO}_{2}-\cdots$ & 64.34 & 65.30 & 63.99 & 61.72 & 64.33 & 62.50 & 67.06 & 66.10 & 62.84 & 64.26 & 63.43 & 61.34 & 64.76 & 63.07 & 61.26 & 62.55 & 63.84 \\
\hline $\mathrm{Al}_{2} \mathrm{O}_{3}-\cdots$ & 14.09 & 15.81 & 16.62 & 15.59 & 14.97 & 15.64 & 16.42 & 15.86 & 15.22 & 14.41 & 14.74 & 14.40 & 14.72 & 15.03 & 14.83 & 15.03 & 15.14 \\
\hline $\mathrm{Fe}_{2} \mathrm{O}_{3}-\cdots$ & .00 & .00 & .00 & .00 & .00 & .01 & .09 & .00 & .01 & .00 & .00 & .01 & .00 & .00 & .03 & .01 & .00 \\
\hline $\mathrm{MgO}-$ & .00 & .03 & .02 & .01 & .00 & .01 & .00 & .00 & .02 & .03 & .02 & .05 & .03 & .00 & .02 & .06 & .04 \\
\hline MnO---------- & .00 & .00 & .00 & .00 & .00 & .00 & .01 & .00 & .03 & .01 & .02 & .00 & .00 & .01 & .00 & .00 & .01 \\
\hline 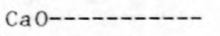 & 7.92 & 7.69 & 8.38 & 8.18 & 8.12 & 7.74 & 8.09 & 8.23 & 8.22 & 8.24 & 8.14 & 8.12 & 8.15 & 8.35 & 8.06 & 8.25 & 8.43 \\
\hline $\mathrm{Na}_{2} \mathrm{O}-----$ & .11 & .18 & .03 & .05 & .05 & .10 & .18 & .16 & .09 & .08 & .12 & .08 & .09 & .10 & .13 & .05 & .09 \\
\hline $\mathrm{K}_{2} \mathrm{O}-\cdots$ & .05 & .08 & .04 & .02 & .02 & .05 & .11 & .06 & .06 & .05 & .09 & .04 & .07 & .04 & .05 & .05 & .03 \\
\hline Total---- & 86.51 & 89.09 & 89.08 & 85.57 & 87.49 & 86.05 & 91.96 & 90.41 & 86.49 & 87.08 & 86.56 & 84.04 & 87.82 & 86.60 & 84.38 & 86.00 & 87.58 \\
\hline \multicolumn{18}{|c|}{ Numbers of atoms on the basis of 48 oxygens } \\
\hline Si---_- & 19.04 & 18.76 & 18.46 & 18.54 & 18.84 & 18.76 & 18.70 & 18.75 & 18.67 & 18.93 & 18.81 & 18.75 & 18.90 & 18.71 & 18.66 & 18.69 & 18.73 \\
\hline 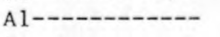 & 4.91 & 5.36 & 5.65 & 5.52 & 5.17 & 5.31 & 5.40 & 5.30 & 5.33 & 5.00 & 5.15 & 5.19 & 5.06 & 5.26 & 5.24 & 5.29 & 5.24 \\
\hline Fe-------- & .00 & .00 & .00 & .00 & .00 & .00 & .02 & .00 & .00 & .00 & .00 & .00 & .00 & .00 & .01 & .00 & .00 \\
\hline Mg----------- & .00 & .01 & .01 & .00 & .00 & .00 & .00 & .00 & .01 & .01 & .01 & .02 & .01 & .00 & .01 & .03 & .02 \\
\hline Mn----------- & .00 & .00 & .00 & .00 & .00 & .00 & .00 & .00 & .01 & .00 & .01 & .00 & .00 & .00 & .00 & .00 & .00 \\
\hline 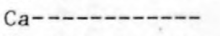 & 2.51 & 2.37 & 2.59 & 2.63 & 2.55 & 2.49 & 2.42 & 2.50 & 2.62 & 2.50 & 2.59 & 2.66 & 2.55 & 2.65 & 2.63 & 2.64 & 2.65 \\
\hline 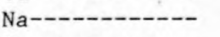 & .07 & .10 & .02 & .03 & .03 & .06 & .10 & .09 & .05 & .05 & .05 & .05 & .05 & .06 & .08 & .03 & .05 \\
\hline K--- & .02 & .03 & .01 & .01 & .01 & .02 & .04 & .02 & .02 & .02 & .03 & .02 & .03 & .02 & .02 & .02 & .01 \\
\hline Si/Al------- & 3.88 & 3.50 & 3.27 & 3.36 & 3.65 & 3.53 & 3.46 & 3.53 & 3.50 & 3.78 & 3.65 & 3.61 & 3.73 & 3.56 & 3.56 & 3.53 & 3.58 \\
\hline $\begin{array}{l}\text { Cat.bal. } \\
\text { error }(\%)^{4---}\end{array}$ & -3.8 & 9.7 & 8.1 & 4.0 & .7 & 5.0 & 9.0 & 3.7 & -.2 & -5.4 & -3.0 & -4.4 & -2.7 & -2.4 & -2.6 & -1.5 & -3.0 \\
\hline
\end{tabular}

${ }^{1}$ Sample numbers correspond to depth in meters.

2 Average of two analy'ses.

4 Averermined by method of Passaglia (1970). 


\section{CLINOPTILOLITE}

Clinoptilolite, usually associated with devitrification $\alpha$-cristobalite in drill core Y-3 (fig. 2), was identified by Xray diffraction analyses as the cementing material in finer grained sediments at $7.3-14.2 \mathrm{~m}$. Clinoptilolite is the only zeolite mineral in this interval. The nearly isotropic mineral also occurs as cement in finer grained siltstone and sandstone and was deposited as tiny $(0.005-0.012 \mathrm{~mm})$, clear, tabular crystals that line cavities (fig. 4) in conglomerate between 16.2 and $26.3 \mathrm{~m}$. Xray diffraction traces of 12 samples from these two zones showed no change in position or intensity of the $(020) \mathrm{X}$ ray peak at about $9 \AA$ after heating according to the method of Mumpton (1960), and the mineral was identified as clinoptilolite.

A single microprobe chemical analysis of clinoptilolite was obtained from $12.4 \mathrm{~m}$ (table 2). This analysis indicates that clinoptilolite at this depth is low in silica, contains very little calcium, and is rich in sodium and, in particular, potassium. The Y-3 clinoptilolite is much lower in calcium than most other heulandite-group zeolites from Yellowstone drill cores, and it is nearly as rich in potassium as some clinoptilolites from drill cores Y-7 and Y-8 (Keith and others, 1978b) (fig. 5).

Three core samples from 24.2 to $26.3 \mathrm{~m}$ and drill cuttings recovered from about $29-30 \mathrm{~m}$ are characterized by splitting of the (020) X-ray peak into three peaks at about $8.9,8.7$, and $8.3 \AA$ following heat treatment. No chemical analyses were obtained for the three

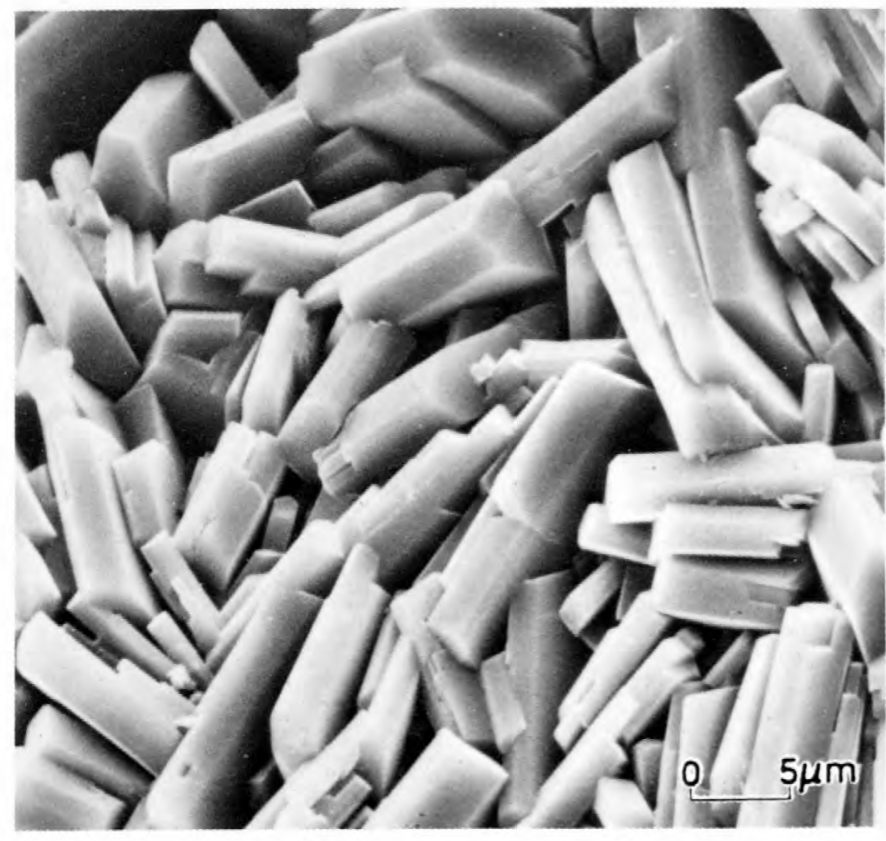

Figure 4.-Scanning electron micrograph of intergrown tabular clinoptilolite crystals from $14.0 \mathrm{~m}$ in drill core Y- 3 (after Bargar and others, 1981). core samples; however, we would predict that they contain more calcium than the above clinoptilolite samples and are probably intermediate heulandites (Alietti, 1972; Boles, 1972).

\section{DACHIARDITE}

Clear dachiardite crystals are widely scattered between 60.2 and $80.9 \mathrm{~m}$ in the Y-3 drill core. The rare, radiating, blocky crystals are found deposited in cavities along with earlier quartz, later mordenite, and smectite (figs. 6 and 7), and they are later than chalcedony in a few vein fillings.

Microprobe chemical analyses of dachiardite crystals from 60.4 and $73.2 \mathrm{~m}$ in drill core $\mathrm{Y}-3$ are given in table 3. A ternary plot of the exchangeable cations (Ca-Na-K) content in Y-3 dachiardite compared with other published dachiardite analyses is shown in figure 8 . The published analyses are divided into two groups: (1) sodium-rich dachiardite, and (2) intermediate dachiardite (Alberti, 1975; Wise and Tschernich, 1978; Bonardi, 1979; Bonardi and others, 1981). A drill core Y-2 dachiardite analysis (Bargar and Beeson, 1981) plots near the latter group and several dachiardite analyses from sample Y3-60.4 plot near the intermediate group, but these crystals are more calcium rich. Chemical analyses of water from the Y-3 drill hole (table 1) suggest that calcium is lost (precipitates) as the water ascends to the surface (Bargar and others, 1973). The Y3-73.2 sample is very calcium rich, and, to the best of our knowledge, this

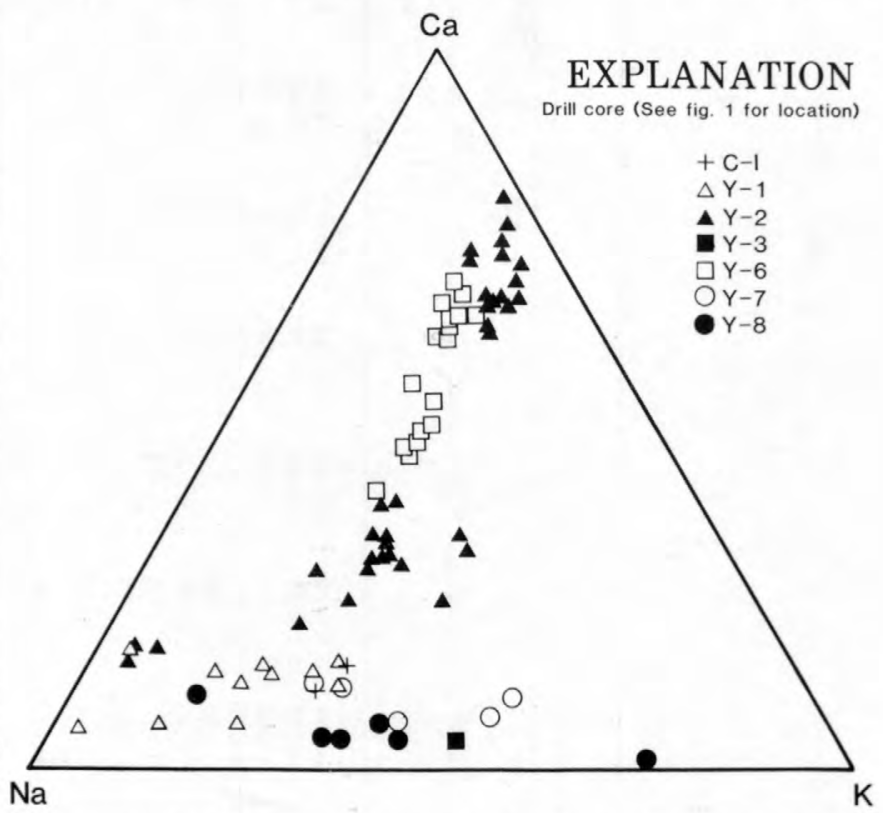

FIGURE 5.-Ca-Na-K ternary diagram for heulandite-group zeolites from Yellowstone drill cores. Data sources as follows: C-I (Fenner, 1936), Y-1 (Honda and Muffler, 1970), Y-2 (Bargar and Beeson, 1981), Y-7 and Y- 8 (Keith and others, 1978b), Y-6 (Bargar and Beeson, 1984), Y-3 (table 3 , this report). 
sample is the only naturally occurring Ca-rich dachiardite ever reported. Ca-rich dachiardite has been produced in the laboratory using devitrified rhyolite as the starting material (Knauss and Beiriger, 1984).

\section{LAUMONTITE}

Many fractures and cavities below $73.2 \mathrm{~m}$ in the Y-3 drill core contain white prismatic laumontite crystals that are up to about $1 \mathrm{~mm}$ in length. SEM studies show that laumontite was deposited later than quartz and earlier than mixed-layer illite-smectite. Some laumontite crystals appear to have been subjected to partial leaching, and the illite-smectite was deposited in the resulting cavities (fig. 9).

Chemical analyses of laumontite from 73.2 and 126.9 $\mathrm{m}$ (by electron microprobe and conventional rock analysis methods) are given in table 2 . The Y-3 laumontite is calcium rich and is very similar to several microprobe analyses of hydrothermal, burial metamorphic, and surficial hot-spring-deposited laumontite (McCulloh and others, 1981). The measured temperature range at which Y-3 laumontite was found was about $167-196{ }^{\circ} \mathrm{C}$.

\section{MORDENITE}

Mordenite is the most abundant zeolite mineral found in the Y-3 drill core. Scattered mordenite deposits occur

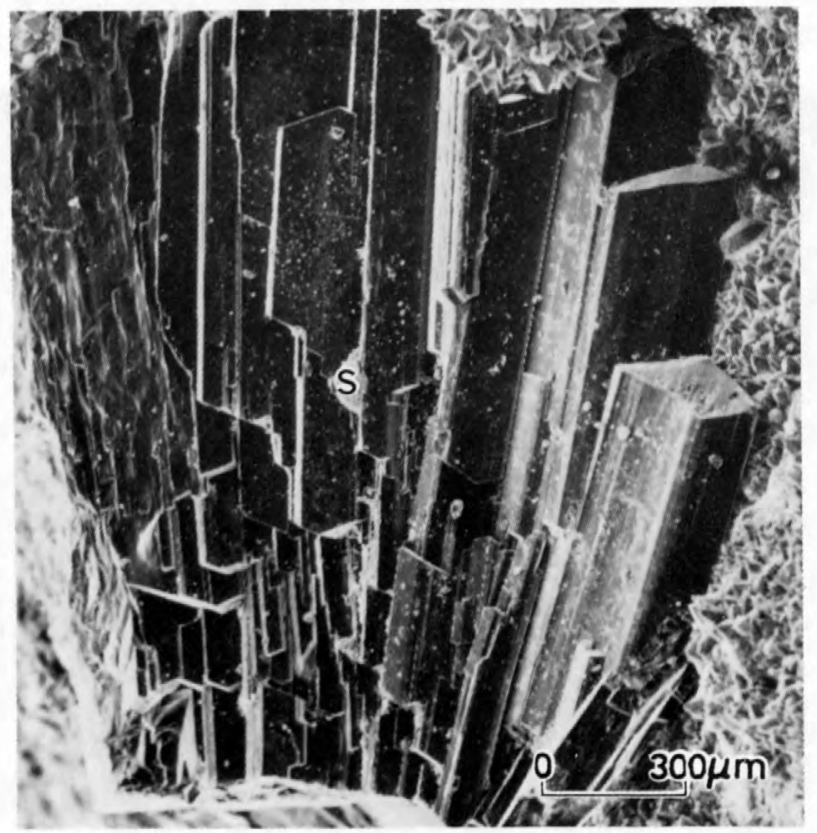

FiguRE 6.-Scanning electron micrograph of a large radiating cluster of dachiardite crystals deposited on hydrothermal quartz crystals (top and right side of photo) in a vug at $60.2 \mathrm{~m}$ in the Y-3 drill core. Smectite crystal cluster (s) was deposited later than dachiardite (after Bargar and others, 1981). in many vugs and fractures throughout much of the drill core as radiating, long, thin, fibrous crystals (fig. 7), as

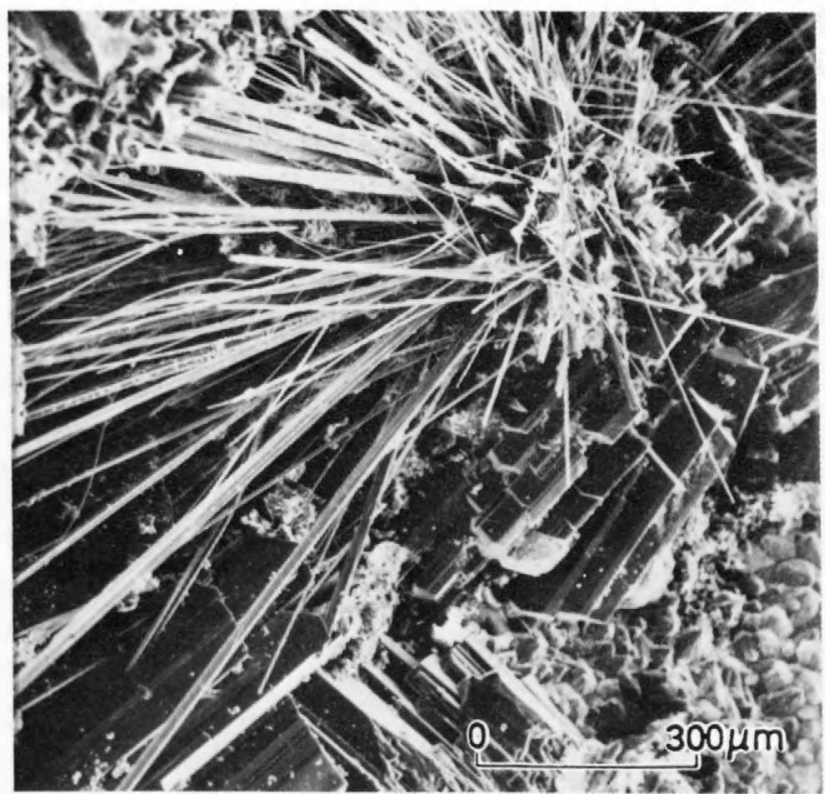

FiguRE 7.-Scanning electron micrograph of cavity filling from $60.2 \mathrm{~m}$ in the Y-3 drill core. Micrograph shows, in apparent depositional sequence, quartz crystals (upper left and lower right), dachiardite (blocky crystals extending diagonally from lower left to right center), radiating fibrous mordenite crystals, and numerous tiny smectite crystal clusters (after Bargar and others, 1981).

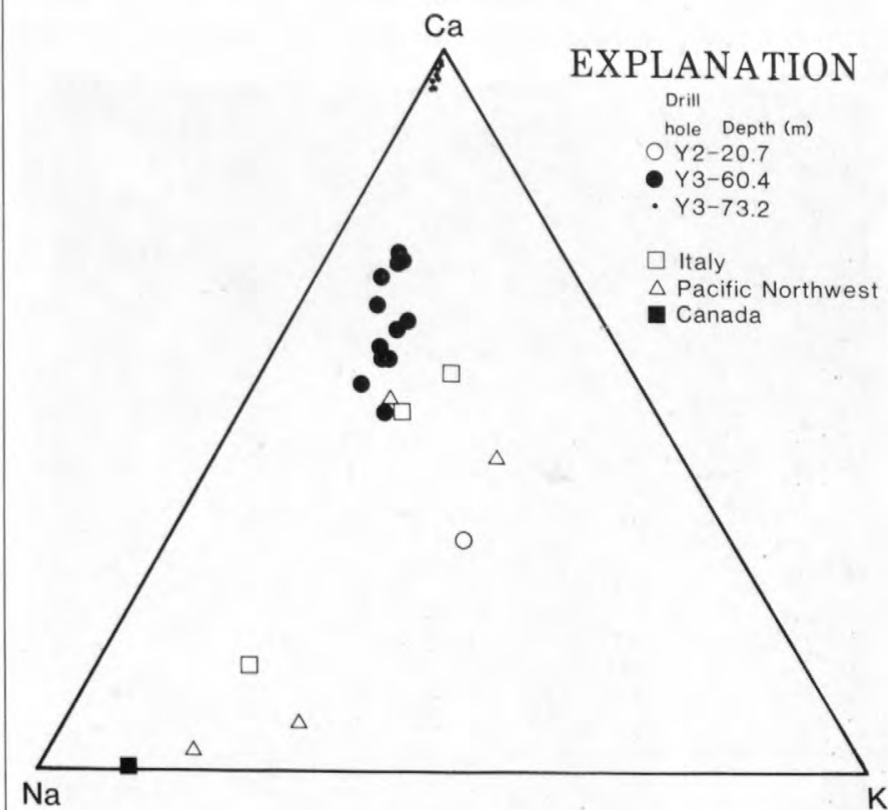

Figure 8.-Ca-Na-K ternary diagram for Y-3 dachiardite compared with other published dachiardite analyses. Data sources as follows: Y3-60.4 and Y3-73.2 (table 3, this report), Y2-20.7 (Bargar and Beeson, 1981), Pacific Northwest (Wise and Tschernich, 1978), Italy (Bonardi, 1979; Alberti, 1975), Canada (Bonardi and others, 1981). 
mats of interwoven fibers, or as needlelike crystals (fig. 10). SEM studies show that mordenite formed later than silica and most other zeolite minerals and earlier than some clay deposits (figs. 7 and 10).

Electron microprobe chemical analyses of coarse mordenite fibers from $91.4 \mathrm{~m}$ are given in table 2 along with $\mathrm{H}_{2} \mathrm{O}$ values that were determined by conventional rock analysis methods. None of the microprobe analyses total to 100 percent even with the accurate $\mathrm{H}_{2} \mathrm{O}$ values, and cation balance errors are high for all but two (1 and 4 in table 2) of the analyses. Nevertheless, the microprobe analyses indicate that sodium and calcium are the major cations and that potassium is a minor constituent; these results are similar to that from a conventional rock analysis of mordenite by Sheppard and Gude (1969) (fig. 11).

\section{YUGAWARALITE}

Yugawaralite is a rare zeolite mineral that has been reported from only a few locations in the world (Zeng and Liou, 1982). Clear, tabular yugawaralite crystals (fig. 12) were deposited in vugs, veins, and fractures of four scattered samples between 71.8 and $75.2 \mathrm{~m}$, where the temperature measured during drilling was about $170{ }^{\circ} \mathrm{C}$. The open-space yugawaralite crystals were deposited later than chalcedony and quartz and earlier than clay. Other zeolite minerals (mordenite, dachiardite, laumontite, and stilbite) appear to be closely associated with yugawaralite; calcite, smectite, pyrite, and

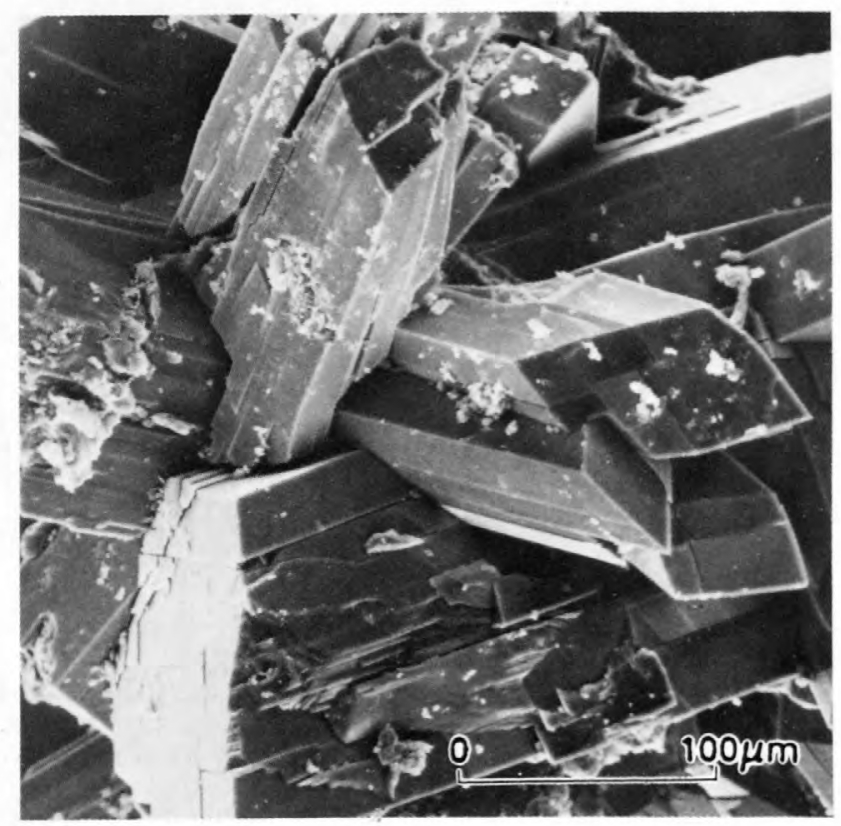

Figure 9.-Scanning electron micrograph of laumontite crystals from $85.4 \mathrm{~m}$ in drill core Y-3. Tiny crystal clusters of mixed-layer illitesmectite are deposited on laumontite crystal surfaces and in solution cavities(?) (left center of photo). chlorite also occur in the yugawaralite-bearing samples.

The idealized unit cell content of yugawaralite is $\mathrm{Ca}_{4}\left(\mathrm{Al}_{8} \mathrm{Si}_{20} \mathrm{O}_{56}\right) 16 \mathrm{H}_{2} \mathrm{O}$ (Barrer, 1982). Several microprobe chemical analyses of yugawaralite from the Y-3 drill core at $73.2 \mathrm{~m}$ (table 2) show that calcium is the dominant cation and that only minor amounts of sodium and potassium are present. The Y-3 chemical analyses are very similar to analyses of yugawaralite made by Eberlein and others (1971), Pongiluppi (1977), Wise (1978), and Zeng and Liou (1982).

\section{STILBITE}

Stilbite, a fairly common zeolite mineral in andesitic and basaltic volcanic terranes (Deer and others, 1963), is extremely rare in the rhyolitic rocks of the Yellowstone volcanic region. In fact, stilbite was only tentatively identified by X-ray diffraction from a single vein filling at $73.2 \mathrm{~m}$ (fig. 13) along with yugawaralite, dachiardite, laumontite, quartz, and chalcedony.

\section{CALCITE}

White, bladed calcite crystals (up to about $3 \mathrm{~cm}$ long) line cavities and fractures in the Y-3 drill core as shallow as $12.1 \mathrm{~m}$. Calcite is sparsely distributed in the glacial sediments and the Nez Perce Creek rhyolite flow, but below about $100 \mathrm{~m}$ in the unnamed rhyolite flow, which composes the lower one-third of the drill core, calcite is present in most samples studied. Calcite appears to

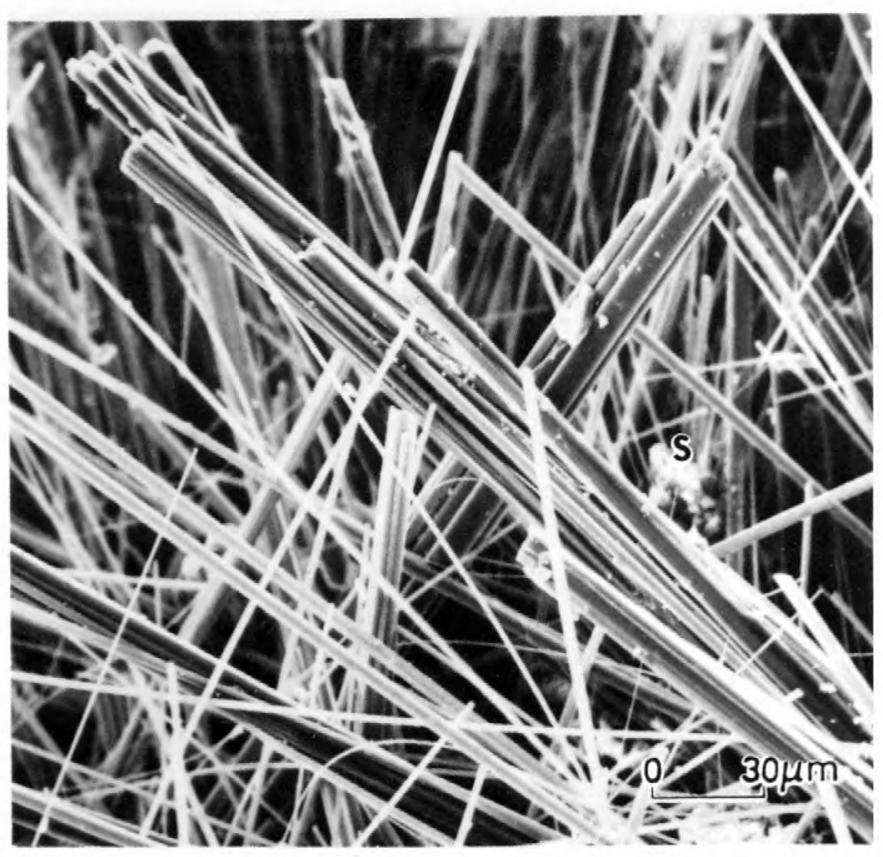

FIGURE 10.-Scanning electron micrograph of fibrous mordenite crystals deposited at $60.2 \mathrm{~m}$ in drill core Y-3. A few mordenite needles are coated by later smectite (s). 
have formed in the middle of the paragenetic sequence of minerals and is generally deposited later than chalcedony, pyrite, hematite, quartz, and chlorite, and before later quartz, zeolite, smectite, and illite-smectite.

\section{FLUORITE}

According to Browne (1978), fluorite, a common hydrothermal mineral, appears to be an uncommon hydrothermal deposit in presently active geothermal systems, and it has been reported only from Java and from several drill cores in Yellowstone National Park. Fluorite in drill core Y-3 is very sparse above about $91 \mathrm{~m}$ but is somewhat more abundant below that depth. White, spherical fluorite was identified in the lepidoliteaegirine-pectolite zone at about $27.5 \mathrm{~m}$. Deeper fluorite deposits are usually massive or consist of clear octahedral crystals that formed earlier than clay and zeolite minerals and later than early quartz crystals. Fluorite is observed in association with calcite, but the order of deposition is not clear. A chemical analysis of water from $88 \mathrm{~m}$, at the top of the lower fluorite zone, shows a high fluoride content (about $30 \mathrm{ppm}$ ) (Bargar and others, 1973).

\section{CLAY AND MICA MINERALS}

\section{KAOLINITE}

White to yellow-stained kaolinite was identified by $\mathrm{X}$-ray diffraction in fractures, vugs, and whole-rock

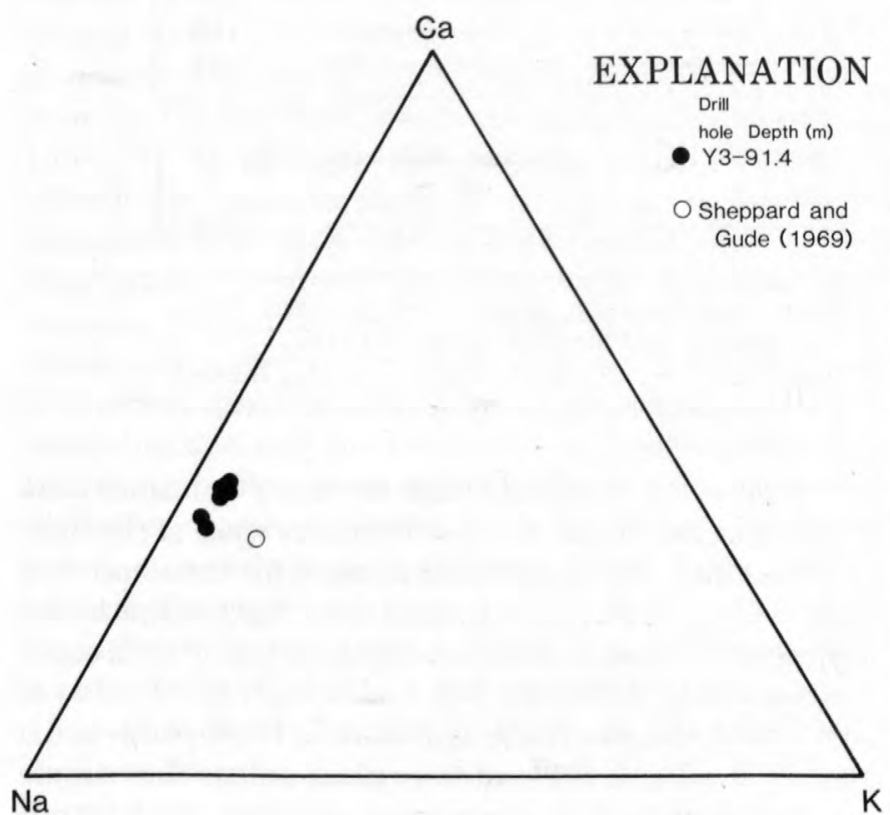

Figure 11.-Ca-Na-K ternary diagram for microprobe chemical analyses of mordenite from $91.4 \mathrm{~m}$ in drill core Y-3 compared with a mordenite analysis given by Sheppard and Gude (1969). alteration in six zones dispersed between the surface and $71.3 \mathrm{~m}$ in drill core Y-3 (fig. 2). In the upper zone $(1.4-5.8 \mathrm{~m})$, kaolinite is found in association with opal, alunite, allophane, halloysite, pyrite, hematite, smectite, and gypsum. Much of this assemblage probably

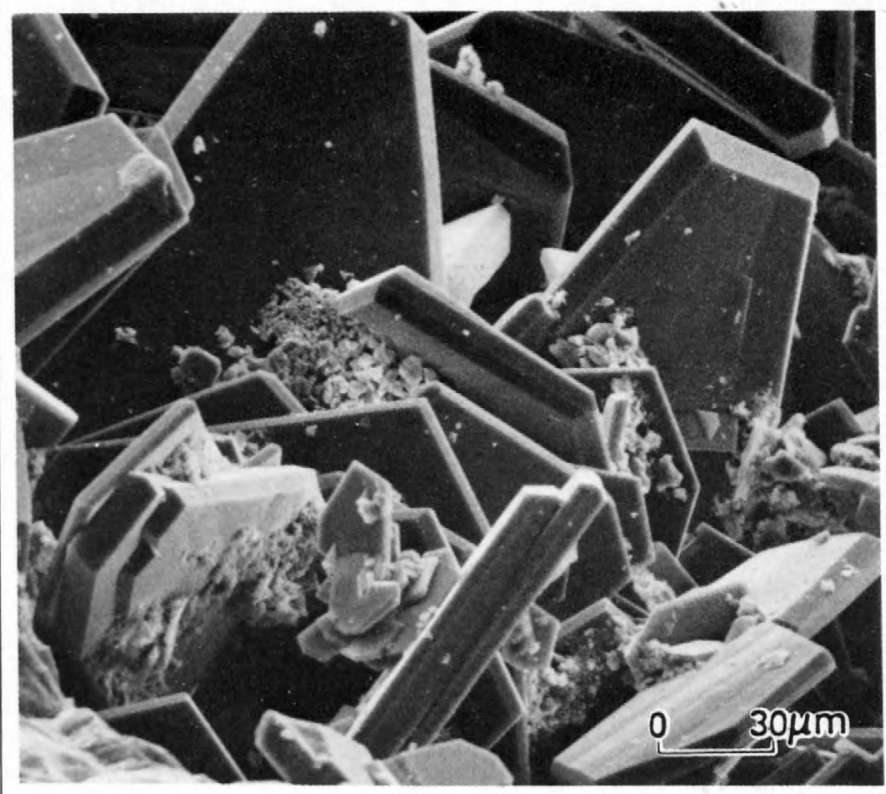

FIGURE 12.-Scanning electron micrograph of euhedral crystals of yugawaralite with later smectite deposits at $73 \mathrm{~m}$ in drill hole Y-3 (after Bargar and others, 1981).

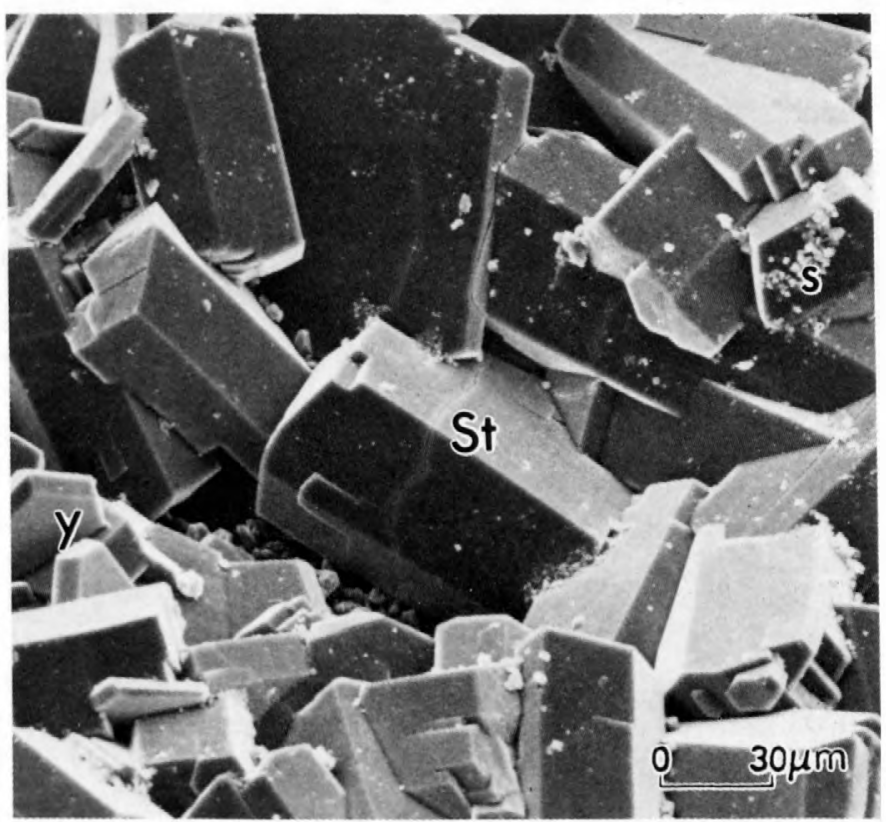

FIGURE 13.- Scanning electron micrograph of blocky stilbite(?) crystals (St) intergrown with tabular yugawaralite (y) and later smectite $(\mathrm{s})$ on a fracture surface at $73.2 \mathrm{~m}$ in drill core Y-3 (after Bargar and others, 1981). 
formed as a result of acid-sulfate alteration. A similar mineral assemblage occurs in Yellowstone drill core Y-11 from a vapor-dominated geothermal system (Muffler and Bargar, 1974; Bargar and Muffler, 1982). Schoen and others (1974) also attributed a similar assemblage of minerals from Steamboat Springs, Nevada, to surficial acid $\left(\mathrm{H}_{2} \mathrm{SO}_{4}\right)$ alteration. Two additional kaolinite zones (41.7-44.4 $\mathrm{m}$ and $68.7-71.3 \mathrm{~m}$ ) contain associated smectite and pyrite and are nearly coincident with stratigraphic breaks between the glacial sediments and the top of the Nez Perce Creek rhyolite flow and between the Nez Perce Creek flow and the older, unnamed rhyolite flow. However, fossil zones of surficial acid alteration are precluded in these two zones because the kaolinite is a late hydrothermal product and is deposited on top of quartz. The kaolinite may have formed due to alteration of K-feldspar by descending meteoric waters that were acidified by oxidation of pyrite. Fenner (1936) describes a similar process for kaolinite formation in drill core C-II (fig. 1).

\section{HALLOYSITE AND ALLOPHANE}

At $1.7 \mathrm{~m}$, kaolinite is the predominant clay mineral; however, some halloysite and allophane are also present. Halloysite has a broad X-ray diffraction peak at about $7.7 \AA$, which, upon heating to $140^{\circ} \mathrm{C}$ for 15 hours, becomes sharper, higher, and shifts to about $7.3-\AA$ (Birkeland, 1969). In addition, one of the X-ray traces of this sample contained a low, broad $\sim 11.5 \AA$ peak that was not affected by heating and might be an allophane peak; allophane is commonly associated with kaolinite and halloysite (Deer and others, 1962). Subsequent testing, involving a small amount of powdered sample placed upon phenolpthalein-treated filter paper to which a drop of $1 M \mathrm{NaF}$ was later added, confirmed the identification of allophane by turning the indicator paper to a pinkish-red color (Fieldes and Perrott, 1966).

\section{CHLORITE}

Chlorite occurs throughout most of the two rhyolite flows as fillings in fractures and cavities and as wholerock alteration adjacent to a few fractures. Open-space chlorite deposits formed later than chalcedony, hematite, quartz, smectite, and mixed-layer illite-smectite, and before late quartz crystals, late pyrite, and zeolite minerals. X-ray diffraction analyses show that the (001) and (003) X-ray peaks are weak and that the (002) and (004) reflections are strong, which suggests that the Y-3 chlorite is an iron-rich mineral (Grim, 1968). The X-ray data were confirmed by a wet chemical analysis of chlorite scraped from a large cavity at $108.3 \mathrm{~m}$ (table 4). This analysis shows that the $\mathrm{Y}-3$ chlorite is iron rich $\left[\mathrm{Fe}^{2+} /\left(\mathrm{Fe}^{2+}+\mathrm{Mg}\right)=0.914\right]$. Very small amounts
TABLE 4.-- Chemical composition of chlorite from $108.3 \mathrm{~m}$ in drill core $\mathrm{Y}-3^{1,2}$

\section{Weight percent}

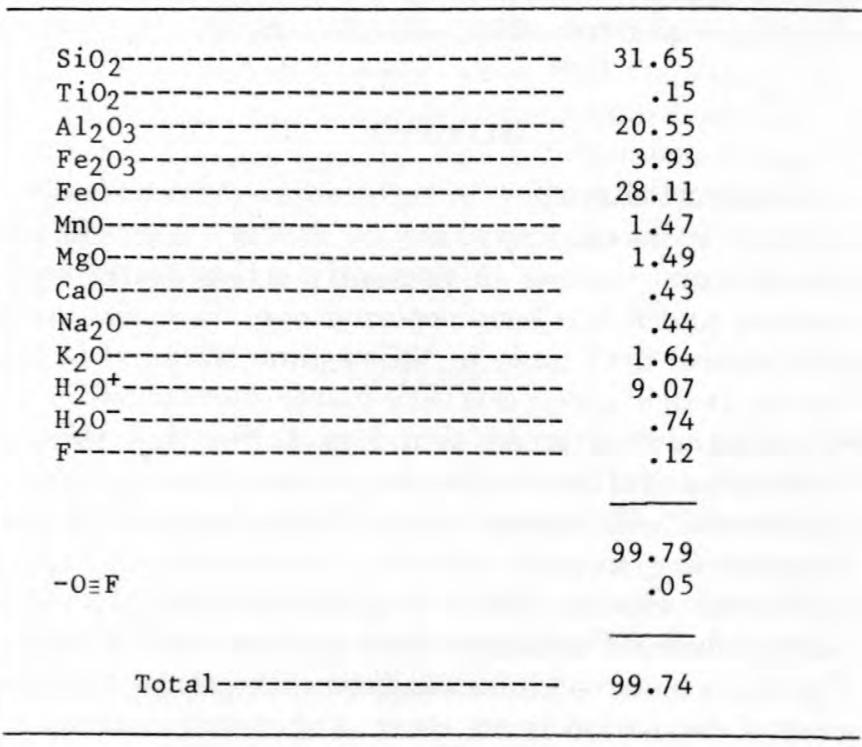

Numbers of atoms on the basis of 36 oxygens

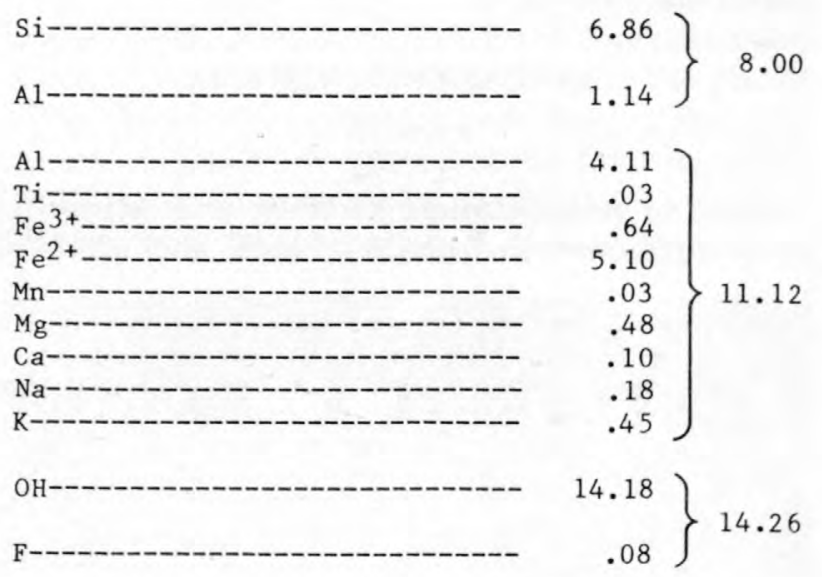

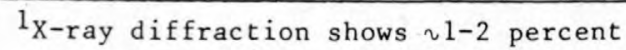
quartz and hematite impurities.

2Analysts: S. T. Neil and J. H. Christie. Analysis by conventional rock-analys is methods .

$(<\sim 2$ percent $)$ of quartz and hematite contaminants were identified on an X-ray diffraction trace of the analyzed sample, and these could account for the somewhat high $\mathrm{SiO}_{2}$ and $\mathrm{Fe}_{2} \mathrm{O}_{3}$ values. A low $\mathrm{MgO}$ value is not unexpected because of the low $\mathrm{MgO}$ content of both rocks and waters in drill hole $\mathrm{Y}-3$, and a high $\mathrm{MnO}$ value is possible in chlorite (Deer and others, 1966); however, a high $\mathrm{K}_{2} \mathrm{O}$ value is difficult to explain unless the sample was contaminated by phenocryst sanidine. No feldspar was detected by X-ray diffraction. 


\section{SMECTITE}

White, light-gray, or green smectite is the predominant clay mineral in much of the upper $80.6 \mathrm{~m}$ of the Y-3 drill core. The smectite commonly occurs as an alteration product of glass, and it was deposited in cavities and on fractures. X-ray diffraction analyses show that the smectite basal (001) spacing varies from about 12 to $15 \AA$ and expands to about $17 \AA$ when treated with ethylene glycol for 1 hour at $60^{\circ} \mathrm{C}$. In the lower part of this range $(12.5 \AA)$ sodium is the exchangeable cation, and at the upper end of the range (14.5-15.5 $\AA$ ) calcium should be the exchangeable cation (Grim, 1968). Using these criteria, calcium is the predominant cation in the smectite above $11.3 \mathrm{~m}$ and from 48.8 to $80.6 \mathrm{~m}$ in the Y-3 drill core; between these depths (11.3-48.8 m), sodium is the major cation, with occasional calcium-rich samples.

\section{ILLITE-SMECTITE}

Mixed-layer illite-smectite occurs as open-space fillings and whole-rock alteration below $80.6 \mathrm{~m}$ and can be found in a few shallower samples. X-ray diffraction traces show an air-dried basal (001) peak at about 10-12 $\AA$ for the mixed-layer clay that splits into two peaks at about 11-14 $\AA$ and 9.1-9.9 $\AA$ following glycolation. According to data given by Hower (1981), these samples appear to contain about $60-80$ percent illite layers and are probably allevardite ordered.

\section{LEPIDOLITE}

Lepidolite, generally considered to be a high-temperature vein, pegmatite, granite, or aplite-associated deposit (Deer and others, 1966), was identified as an intergranular cavity filling in conglomerate and coarsegrained sandstone at $23.8 \mathrm{~m}$ and between 27.2 and 28.5 $\mathrm{m}$ in the Y-3 drill core, where the temperature was about 130-140 ${ }^{\circ} \mathrm{C}$ (Bargar and others, 1973). The polycrystalline lepidolite mats (fig. 14) appear to have been deposited later than analcime and quartz and earlier than pectolite and aegirine. Other hydrothermal minerals identified in the lepidolite-bearing samples include chalcedony, calcite, fluorite, kaolinite, and pyrite. X-ray diffraction and chemical data for the polylithionite (a lepidolite end member) are given in Bargar and others (1973). According to Bargar and others (1973), the water that deposited lepidolite in the Y-3 drill hole is anomalously rich in lithium and fluoride, which are the two chemical constituents necessary for the formation of lepidolite. A barely perceptible 10 - $\AA$ mica X-ray diffraction peak was noted in a few scattered samples at 1.4, $13.0-15.2,43.8-47.0$, and $65.5-66.1 \mathrm{~m}$. The $10-\AA \AA$ mica was not observed in thin section, and its origin is uncertain.

\section{AEGIRINE}

In drill core Y-3, bright-green, pleochroic aegirine occurs as spherical or radiating clusters of euhedral bladed-to-prismatic crystals that are up to about $15 \mu \mathrm{m}$ in length (figs. $15 A, B$ ). Aegirine is closely associated with pectolite at depths of 26.3-28.5 and 65.5-66.3 m; in the shallower zone, the two minerals were deposited in intergranular cavities in coarse sediments, whereas in the deeper zone, the minerals were deposited in fractures and cavities formed by leaching of sanidine phenocrysts. Aegirine is a fairly rare mineral in modern geothermal systems; previously, it was identified in Yellowstone drill cores Y-1 (Honda and Muffler, 1970), Y-2 (Bargar and Beeson, 1981), and Y-13 (Keith and others, 1978a).

Figure 16 is a ternary diagram of acmite-jadite-hedenbergite + diopside $(\mathrm{Ac}-\mathrm{Jd}-\mathrm{Hd}+\mathrm{Di})$ electron microprobe compositions of aegirine from drill core Y-3 (table 5) compared with analyses of Y-2 hydrothermal aegirine (Bargar and Beeson, 1981). End-member compositions were calculated according to the method of Cawthorn and Collerson (1974).

\section{PECTOLITE}

Pectolite is not an uncommon hydrothermal mineral, but, according to Browne (1978), this calcium-sodium silicate hydrate mineral is rare in active geothermal fields and has been identified only in the Y-3 drill core (at depths of 26.3-28.5 and 65.5-66.3 m) and in discharge pipes and channels of the New Zealand volcanic zone. In drill core Y-3, pectolite occurs as white fibrous crystals (figs. $15 A, 15 B$, and $17 A$ ) or as radiating clusters of bladed crystals (fig. 17B) that were deposited later than aegirine and quartz.

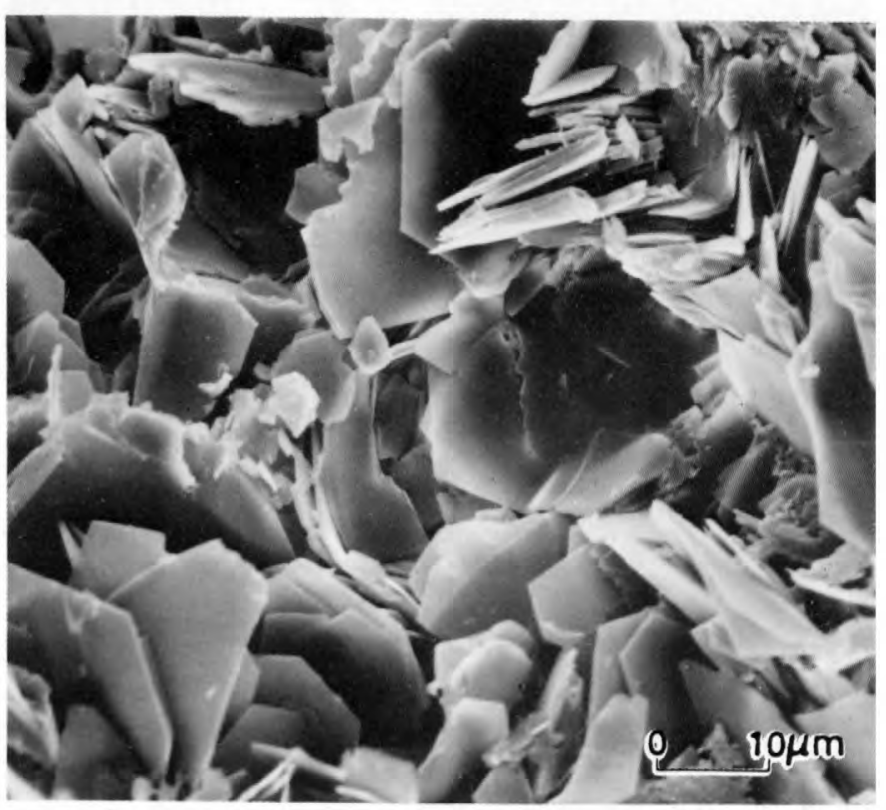

Figure 14.-Scanning electron micrograph of a polycrystalline mat of lepidolite crystals from $28.3 \mathrm{~m}$ in drill core $\mathrm{Y}-3$. 


\section{TRUSCOTTITE}

Truscottite, another calcium silicate hydrate mineral, was identified in the Y-3 drill core from between 87.8 and $89.8 \mathrm{~m}$, where the temperature measured during drilling was about $175^{\circ} \mathrm{C}$. (Truscottite has been formed in the laboratory from gyrolite and silica at $180{ }^{\circ} \mathrm{C}$ (Minato and Kato, 1967).) Clear, tabular truscottite crystals (fig. 18) were deposited in cavities and on fractures
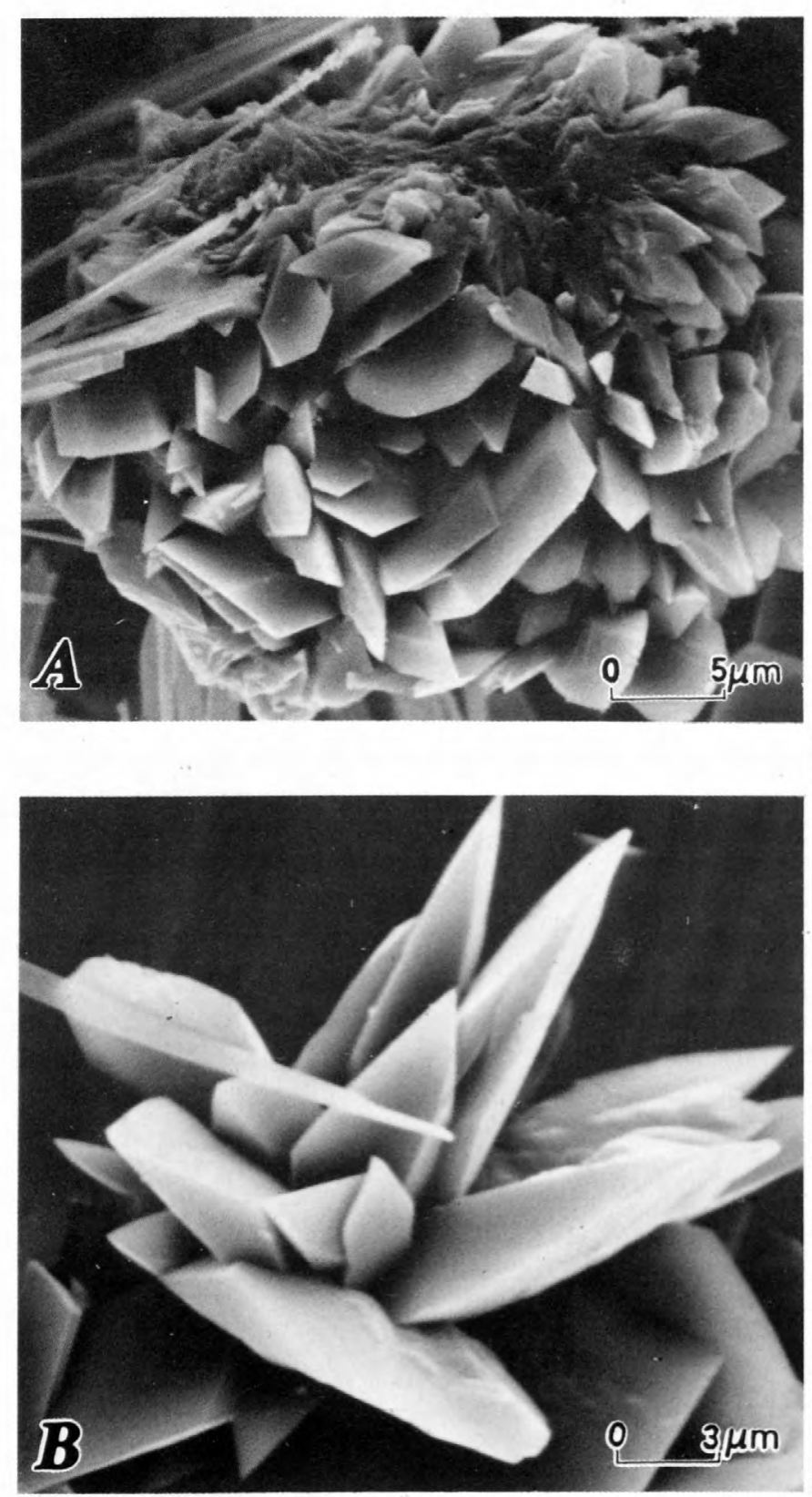

FIGURE 15.-Scanning electron micrographs from drill core Y-3 at $65.5 \mathrm{~m}$. A, Spherical cluster of aegirine crystals and later pectolite fibrous crystals. $B$, Radiating clusters of aegirine crystals and later pectolite fiber. and are associated with earlier chalcedony, quartz, calcite, and laumontite, and later smectite and mordenite; Y-3 truscottite-bearing samples also contain chlorite and pyrite. Truscottite previously had been identified in three other Yellowstone drill cores (Y-2, Y-13, and C-I) (Keith and others, 1978a; Bargar and Beeson, 1981; Bargar and others, 1981). Several microprobe analyses of truscottite from $88.6 \mathrm{~m}$ in drill core Y-3 (table 6) suggest that this occurrence is slightly more calcium rich (chemical analyses of Y-3 drill-hole water compared with water from nearby Ojo Caliente Hot Spring, shown in table 1, suggest that calcium is precipitated during ascent of the water to the surface), is silica deficient, and has slightly greater alumina content than is found in most published analyses of the mineral (Minato and Kato, 1967; Juan and others, 1970) (fig. 19).

\section{SULFATE MINERALS}

GYPSUM

Gypsum occurs in a few scattered samples above 21.5 $\mathrm{m}$ in the Y-3 drill core. In the shallowest samples, white gypsum fibrous crystals line cavities and veins at less than $57{ }^{\circ} \mathrm{C}$ (the greatest temperature at which gypsum is the stable calcium sulfate phase) (Holland, 1967), and the mineral may be of hydrothermal origin. However, in deeper samples the gypsum is mostly deposited in association with pyrite and was probably formed by oxidation after the drill core was brought to the surface.

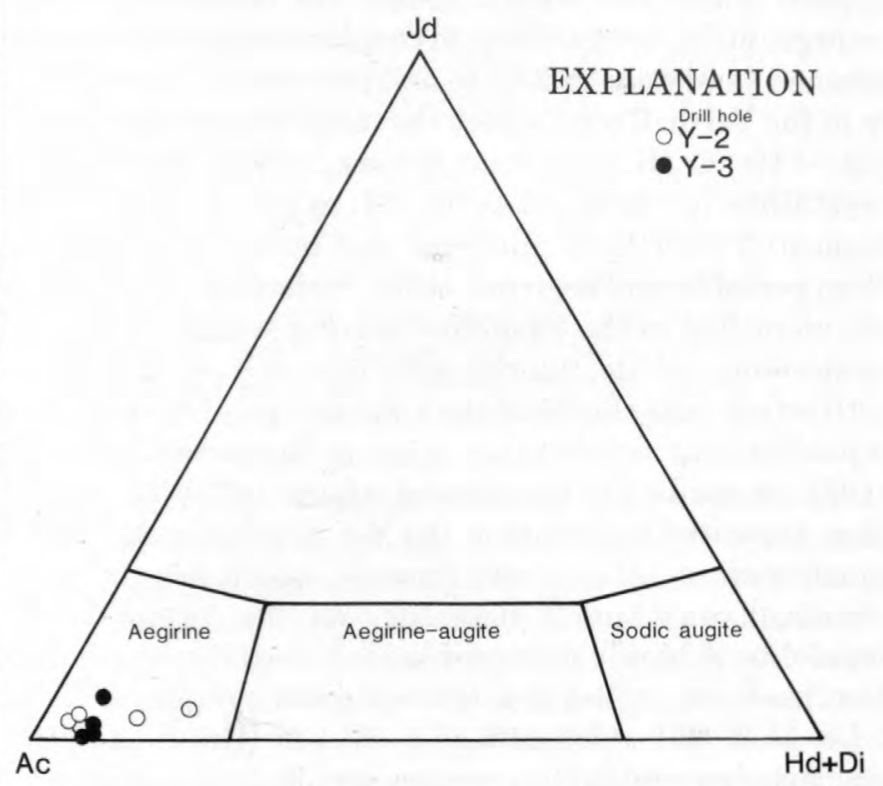

Figure 16.- Ac - Jd - Di $+\mathrm{Hd}$ ternary diagram for aegirine from drill core Y-3 (data from table 5, this report) compared with Y-2 aegirine reported by Bargar and Beeson (1981). 
ALUNITE

Alunite, a potassium sulfate mineral, occurs in a single sample at $1.6 \mathrm{~m}$ in drill core Y-3 in association with opal, kaolinite, allophane, and halloysite. White and others $(1975$, table 3$)$ indicate that the depth to the water table in drill hole Y-3 was about $2.4 \mathrm{~m}$. Thus, alunite in Y-3 appears to have formed in the unsaturated zone of the drill core as a result of near-surface acid alteration, as described by Schoen and others (1974).

\section{HEMATITE}

Orange-red-reddish-brown iron oxide is sparse above $46 \mathrm{~m}$ and has a sporadic distribution throughout the remainder of the Y-3 drill core. Iron oxide (hematite where identified by X-ray diffraction) commonly occurs as pigment that stains chalcedony fracture fillings and vug deposits; however, occasional earthy or clayey hematite was noted. Hematite is an early hydrothermal mineral and appears to have formed later than chalcedony and pyrite, probably as a result of pyrite oxidation.

\section{PYRITE}

Tiny cubic pyrite crystals are found throughout much of the Y-3 drill core as deposits disseminated in groundmass or earlier green chalcedony. In Y-3, pyrite commonly lines fractures and vugs where the euhedral crystals or thin massive deposits are sometimes associated with later hematite. A few massive pyrite fracture fillings have crude hexagonal-appearing crystal cluster shapes that hint of a possible sulfide (pyrrhotite?) precursor. Pyrrhotite was identified in nearby Yellowstone drill core Y-2 (Bargar and Beeson, 1981). Y-3 pyrite crystals are typically small (about $0.1 \mathrm{~mm}$ ); however, at about $4.5 \mathrm{~m}$ a thin, black, powdery pyrite deposit consists of $0.02-0.03 \mathrm{~mm}$ cubic crystals. At $45.5 \mathrm{~m}$, pyrite

TABLE 5. -- Microprobe analyses of aegirine from $\mathrm{Y}-3$ drill core

\begin{tabular}{|c|c|c|c|c|c|c|c|c|}
\hline \multirow{2}{*}{$\begin{array}{l}\text { Sample No. -- } \\
\text { Analysis No.- }\end{array}$} & \multicolumn{3}{|c|}{ Y3-27.5 } & \multicolumn{5}{|c|}{ Y3-66. 1} \\
\hline & 1 & 2 & 3 & 1 & 2 & 3 & 4 & 5 \\
\hline
\end{tabular}

Weight percent

\begin{tabular}{|c|c|c|c|c|c|c|c|c|}
\hline $\mathrm{SiO}_{2}----$ & 52.60 & 51.39 & 50.26 & 51.27 & 50.58 & 50.68 & 50.31 & 49.70 \\
\hline $\mathrm{A}_{2} \mathrm{O}_{3}-\cdots$ & .19 & .23 & .10 & .16 & .22 & .50 & .19 & 1.28 \\
\hline $\mathrm{Fe}_{2} \mathrm{O}_{3}-\cdots$ & 29.42 & 29.29 & 29.22 & 29.37 & 28.53 & 28.81 & 28.82 & 27.60 \\
\hline $\mathrm{MgO}------$ & .94 & .94 & 1.23 & .99 & .95 & .77 & .74 & .89 \\
\hline $\mathrm{MnO}------$ & 1.05 & .99 & 1.37 & .61 & .61 & .64 & .64 & .50 \\
\hline $\mathrm{CaO}-----$ & .88 & .85 & .70 & 1.25 & 1.55 & 1.68 & 1.28 & 1.09 \\
\hline $\mathrm{Na}_{2} \mathrm{O}------$ & 12.64 & 13.08 & 11.09 & 12.53 & 12.72 & 12.86 & 13.01 & 11.71 \\
\hline $\mathrm{K}_{2} \mathrm{O}-\cdots$ & .12 & .08 & .36 & .08 & .07 & .23 & .07 & .80 \\
\hline Tota1- & 97.84 & 96.85 & 94.24 & 96.26 & 95.23 & 96.17 & 95.06 & 93.31 \\
\hline
\end{tabular}

Numbers of atoms on the basis of 6 oxygens

\begin{tabular}{|c|c|c|c|c|c|c|c|c|}
\hline Si-ーーー-ー-- & 2.05 & 2.03 & 2.03 & 2.01 & 2.03 & 2.02 & 2.02 & 2.02 \\
\hline $\mathrm{A} 1-------$ & .01 & .01 & .00 & .01 & .01 & .02 & .01 & .06 \\
\hline $\mathrm{Fe}--------$ & .86 & .87 & .89 & .87 & .86 & .86 & .87 & .84 \\
\hline $\mathrm{Mg}--------$ & .05 & .06 & .07 & .06 & .06 & .05 & .04 & .05 \\
\hline Mn-------- & .03 & .03 & .05 & .02 & .02 & .02 & .02 & .02 \\
\hline $\mathrm{Ca}--------$ & .04 & .04 & .03 & .05 & .07 & .07 & .06 & .05 \\
\hline $\mathrm{Na}--------$ & .95 & 1.00 & .87 & 1.05 & .99 & .99 & 1.01 & .92 \\
\hline K--- - - - & .01 & .00 & .02 & .00 & .00 & .01 & .00 & .04 \\
\hline
\end{tabular}

\footnotetext{
${ }^{1}$ Sample numbers correspond to depth in meters.
} 
displays an unusual needlelike crystal structure; the brassy needles (deposited later than quartz) are up to about $0.25 \mathrm{~mm}$ in length (fig. 20).

\section{SUMMARY AND DISCUSSION}

The Y-3 drill hole penetrated about $42 \mathrm{~m}$ of surficial deposits consisting primarily of Pinedale glacial sedi-
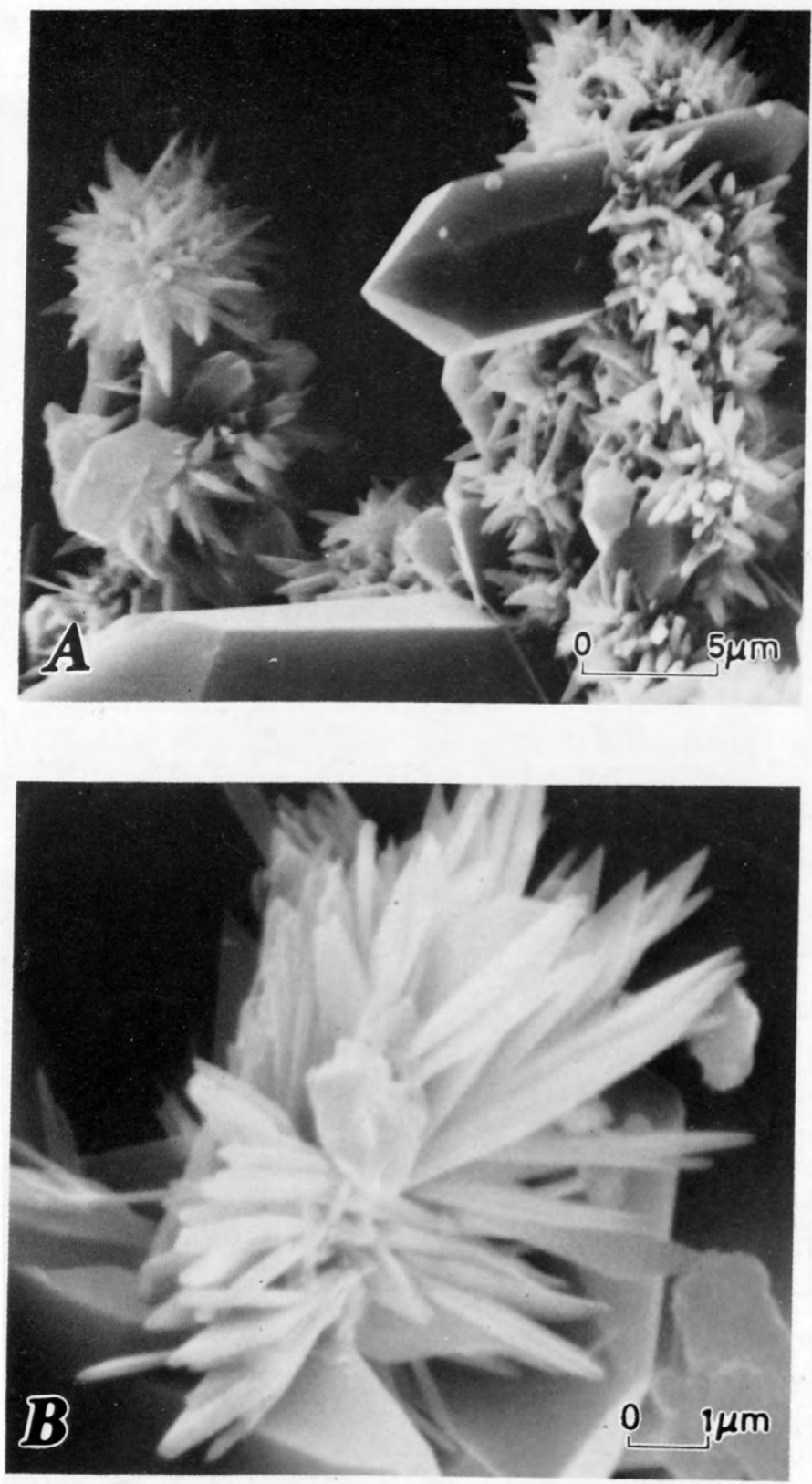

Figure 17.-Scanning electron micrographs from drill core Y-3. A, Clusters of fibrous pectolite crystals deposited on top of hydrothermal quartz crystals at a depth of $28.3 \mathrm{~m}$. B. Cluster of bladed pectolite crystals deposited later than quartz at $27.5 \mathrm{~m}$ (after Bargar and others, 1981). ments that were deposited $\geqslant 45,000-14,000$ years B.P. (Christiansen and Blank, 1974; Pierce and others, 1976). Below $42 \mathrm{~m}$ are two rhyolite flows, the Nez Perce Creek flow and an older, unnamed rhyolite flow, that Chris-

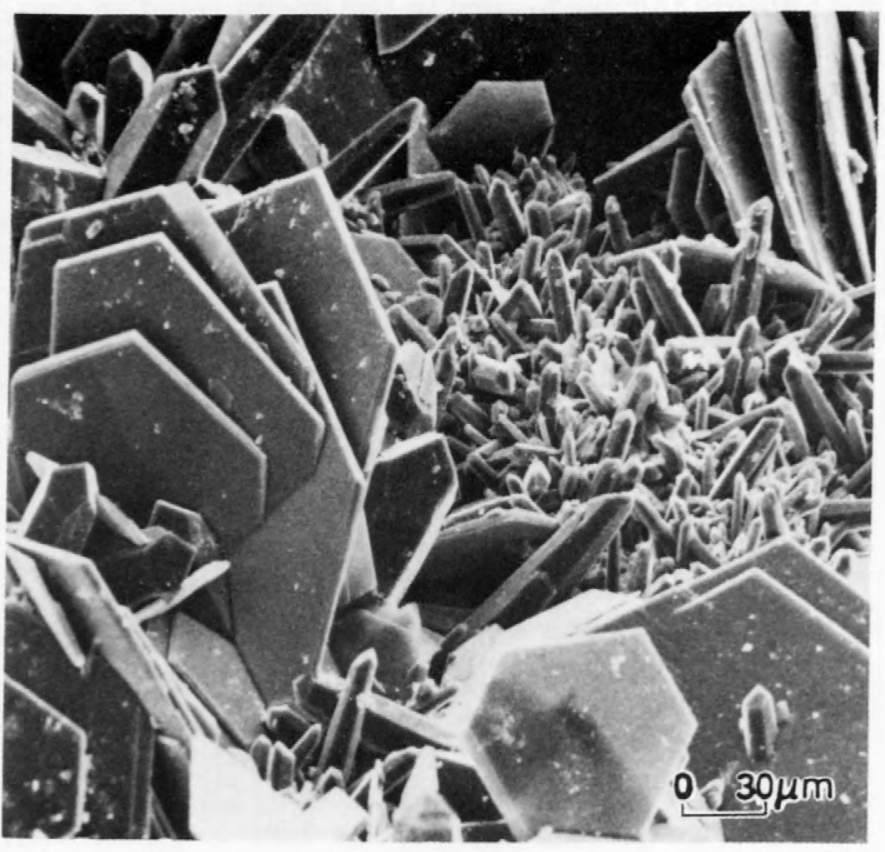

FIGURE 18.-Scanning electron micrograph of tabular, hexagonal crystals of truscottite deposited later than quartz at $88.6 \mathrm{~m}$ in drill core Y-3 (after Bargar and others, 1981).

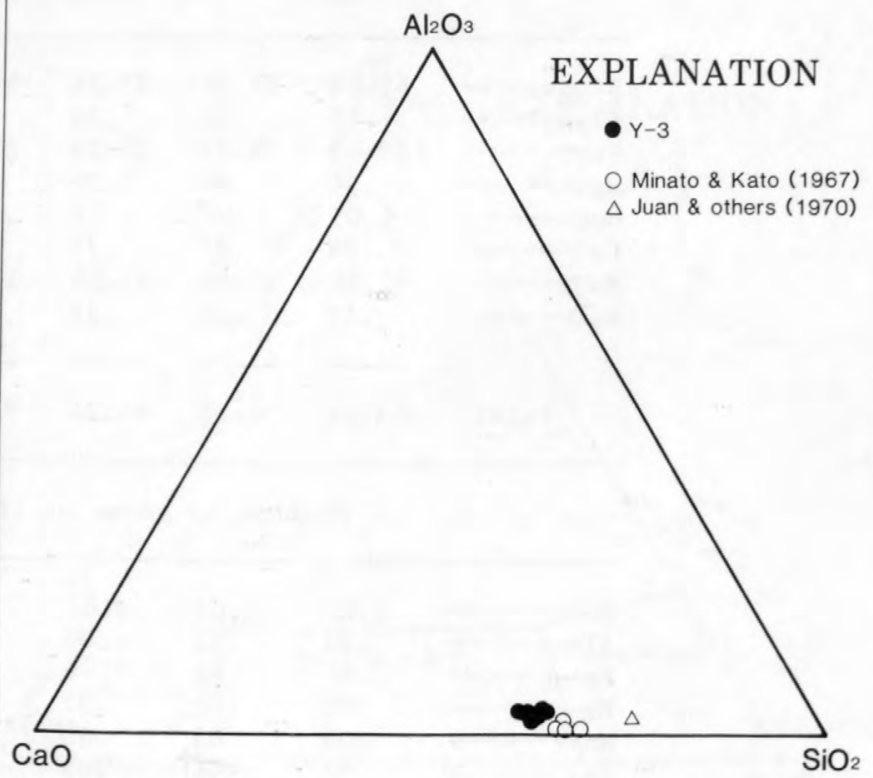

Figure 19.- $\mathrm{CaO}-\mathrm{Al}_{2} \mathrm{O}_{3}-\mathrm{SiO}_{2}$ molecular-proportion ternary diagram for truscottite from $88.6 \mathrm{~m}$ in drill core Y- 3 (data from table 6 , this report) compared with published analyses of truscottite reported by Minato and Kato (1967) and Juan and others (1970). 
TABLE 6. -- Microprobe analyses of truscottite from $88.6 \mathrm{~m}$ in drill core $\mathrm{Y}-3$

\begin{tabular}{|c|c|c|c|c|c|c|c|c|c|c|}
\hline Analysis No.-- & 1 & $2^{1}$ & 3 & 4 & 5 & 6 & 7 & 8 & 9 & 10 \\
\hline \multicolumn{11}{|c|}{ Weight percent } \\
\hline $\mathrm{SiO}_{2}---------$ & 50.99 & 54.28 & 52.53 & 53.74 & 55.03 & 50.97 & 53.20 & 51.66 & 49.19 & $51.56^{\circ}$ \\
\hline $\mathrm{A}_{1}{ }_{2} \mathrm{O}_{3}-\cdots-\cdots$ & 4.29 & 5.15 & 4.54 & 3.39 & 3.08 & 3.72 & 4.70 & 4.59 & 4.47 & 4.40 \\
\hline $\mathrm{Fe}_{2} \mathrm{O}_{3}--$ & .19 & .14 & .62 & .38 & .21 & .18 & .19 & .19 & .14 & .13 \\
\hline $\mathrm{MgO}---------$ & .04 & .06 & .09 & .07 & .06 & .11 & .15 & .08 & .07 & .10 \\
\hline $\mathrm{MnO}-----------$ & .04 & .02 & .05 & .09 & .05 & .06 & .03 & .01 & .04 & .06 \\
\hline $\mathrm{CaO}-\cdots----$ & 25.89 & 27.51 & 29.33 & 29.17 & 30.14 & 27.04 & 29.35 & 29.47 & 28.32 & 25.47 \\
\hline $\mathrm{Na}_{2} \mathrm{O}---\cdots---$ & 1.91 & 1.08 & .62 & .41 & .27 & 1.51 & .68 & .65 & .61 & 1.30 \\
\hline $\mathrm{K}_{2} \mathrm{O}-\cdots$ & .76 & .56 & .59 & .50 & .67 & .69 & .78 & 1.14 & 1.02 & .53 \\
\hline Tota1---- & 84.11 & 88.80 & 83.37 & 87.75 & 89.51 & 84.28 & 89.08 & 87.79 & 83.86 & 83.55 \\
\hline
\end{tabular}

Number of atoms on the basis of 11 oxygens

\begin{tabular}{|c|c|c|c|c|c|c|c|c|c|c|}
\hline Si---D------- & 4.01 & 4.01 & 3.95 & 4.05 & 4.07 & 4.01 & 3.96 & 3.93 & 3.92 & 4.04 \\
\hline $\mathrm{A} 1-\cdots---\cdots$ & .40 & .45 & .40 & .30 & .27 & .34 & .41 & .41 & .42 & .41 \\
\hline $\mathrm{Fe}----------$ & .01 & .01 & .04 & .02 & .01 & .01 & .01 & .01 & .01 & .01 \\
\hline $\mathrm{Mg}-\sim----------$ & .00 & .01 & .01 & .01 & .01 & .01 & .02 & .01 & .01 & .01 \\
\hline Mn------------ & .00 & .00 & .00 & .01 & .00 & .00 & .00 & .00 & .00 & .00 \\
\hline $\mathrm{Ca}----------$ & 2.18 & 2.18 & 2.36 & 2.35 & 2.39 & 2.28 & 2.34 & 2.40 & 2.42 & 2.14 \\
\hline $\mathrm{Na}---------$ & .29 & .15 & .09 & .06 & .04 & .23 & .10 & .10 & .09 & .20 \\
\hline 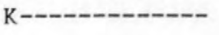 & .08 & .05 & .06 & .05 & .06 & .07 & .07 & .11 & .10 & .05 \\
\hline
\end{tabular}

$1_{\text {Average of three analyses. }}$

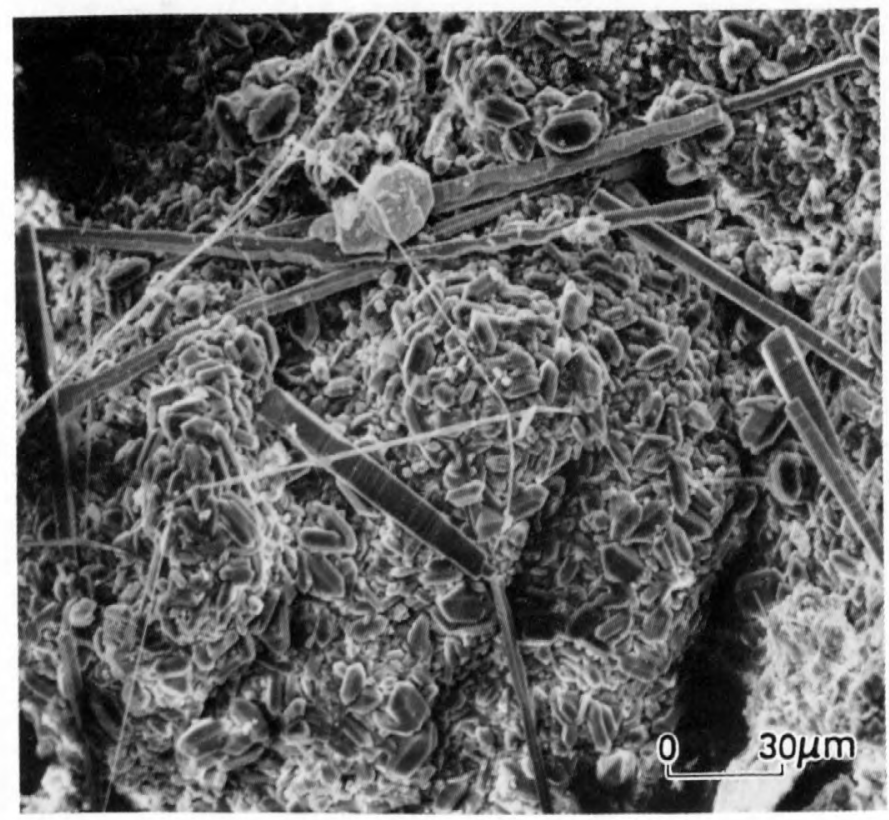

FIGURE 20.-Scanning electron micrograph of pyrite needlelike crystals deposited on top of quartz crystals that line a cavity at $45.5 \mathrm{~m}$ in drill core Y-3. Threadlike material may be mordenite. Smectite crystal clusters also appear to be present.

\section{Early Late}

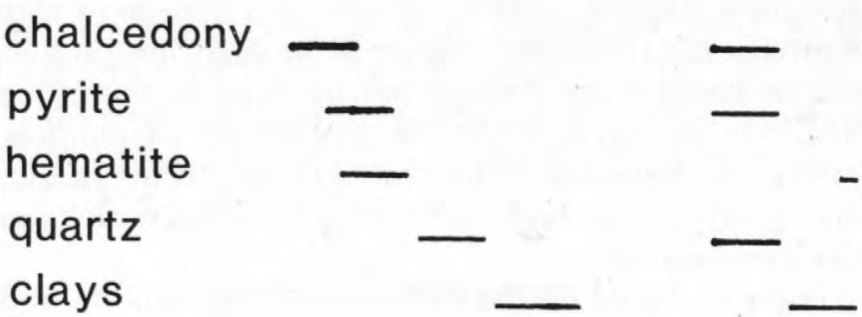

\section{chlorite}

fluorite

zeolites

FIGURE 21.-Generalized paragenetic sequence of principal hydrothermal minerals in drill core Y-3. Length of lines is not indicative of duration of mineral deposition. 
tiansen and Blank (1974) correlated with the Central Plateau Member of the Pleistocene Plateau Rhyolite. The Nez Perce Creek flow has K-Ar dates between 140,000 and 160,000 years B.P., as reported in White and others (1975), Waldrop and Pierce (1975), and Leeman and Phelps (1981). Other rhyolite flows of the Central Plateau Member were extruded between about 200,000 and 70,000 years ago (Christiansen and Blank, 1972). Thus the unnamed rhyolite flow in drill core Y-3 is probably not much older than the overlying Nez Perce Creek flow.

The effects of hydrothermal alteration are evident throughout the Y-3 drill core. Silica and zeolite minerals provide the cementing material for much of the surficial deposits. Parts of the two rhyolite flows were bleached by thermal waters, and the entire drill core contains hydrothermal minerals lining vugs and filling fractures. A generalized paragenetic sequence for the principal hydrothermal minerals found in drill core Y-3 is shown in figure 21 . The glacial sediments and both rhyolite flows probably have been subjected to hydrothermal alteration throughout their histories, because the duration of hydrothermal activity in the Yellowstone region appears to extend over the last 266,000 years and may possibly date back to about 600,000 years B.P. (Silberman and others, 1979). Consequently, some of the hydrothermal minerals in drill core Y-3 probably predate the Pinedale glacial sedimentary deposits of the upper $42.2 \mathrm{~m}$. Chalcedony, pyrite, hematite, quartz, and clay minerals (smectite and mixed-layer illite-smectite) are early hydrothermal deposits in the volcanic section of the drill core (listed in order of deposition); calcite, chlorite, fluorite and zeolite minerals are later deposits, although the depositional sequence of calcite, chlorite, and fluorite was not determined. Chalcedony, pyrite, hematite, quartz, and clays are also shown as late hydrothermal deposits in figure 21 because these minerals are found in the younger sedimentary section of the drill core, as well as in the volcanic section. In addition, pyrite was deposited both earlier and later than quartz, and quartz occurs both earlier and later than calcite in the same sample.

Porosity, based on the difference between bulk- and powder-density measurements, was computed for 16 selected samples of Y-3 drill core. The calculated porosity ranged from 15.7 to 45.8 percent (average 35.1 percent) in the glacial sediments and from 3.7 to 36.9 percent (average 15.3 percent) in the rhyolite flows. The porosity and effective permeability of the volcanic rocks appear to have been greatly reduced owing to precipitation of hydrothermal minerals, particularly quartz and chalcedony, in vugs and fractures. In fact, many of the fractures in the lower, unnamed rhyolite flow have been completely closed (self-sealed) by silica deposition.
According to Pierce (1979, pl. 1), as much as $600 \mathrm{~m}$ of Pinedale glacial ice may have covered the ground surface about $10 \mathrm{~km}$ north of the Y-3 drill hole. In the thermal areas of Lower Geyser Basin, a significant portion of the ice probably melted and formed an ice-dammed lake (Muffler and others, 1971), the possible extent of which is shown by Pierce (1979, fig. 35). Muffler and others (1971) suggest that the triggering mechanism for the nearby hydrothermal explosion crater at Pocket Basin (fig. 1) may have been a sudden release of pressure caused by breaching of the ice dam and rapid draining of the lake. Prior to failure of the dam, the confining pressure at a given depth beneath the ground surface would have greatly exceeded present-day hydrostatic or lithostatic pressures, and the temperature at that depth would have been significantly warmer than the temperature measured during drilling of Y-3. Presumably, the fluid-inclusion homogenization temperature measurements for the Y-3 drill core (and other drill cores in Lower Geyser Basin) that exceed the temperatures measured during drilling reflect the higher temperaturepressure conditions that existed as a result of increased overburden during the Pinedale glacial time (Bargar and others, 1984).

In the sedimentary section of the Y-3 drill core, hydrothermal minerals containing sodium as a dominant cation (analcime, clinoptilolite, mordenite, $\mathrm{Na}$-smectite, and aegirine) are more abundant than calcium-bearing minerals (calcite, fluorite, Ca-smectite, and pectolite). Conversely, in the volcanic section of the drill core, calcium-rich minerals (dachiardite, laumontite, yugawaralite, calcite, fluorite, Ca-smectite, pectolite, and truscottite) are predominant over sodium-bearing minerals (aegirine, mordenite, and Na-smectite). A few hydrothermal minerals that contain significant amounts of potassium (alunite, illite-smectite, and lepidolite) occur in both sections of the drill core.

Rhyolite flows of the Central Plateau Member are similar in chemical composition to the Summit Lake flow (Keith and others, 1978b) and to glass from the Nez Perce Creek flow (Leeman and Phelps, 1981). The analyses of the latter two flows show abundant sodium and potassium and little calcium. Twelve hydrothermally altered rocks from the Nez Perce Creek flow and the underlying unnamed rhyolite flow were analyzed by rapid rock methods and reported by Beeson and Bargar (1984). Figure 22 shows A-F-M and $\mathrm{Na}_{2} \mathrm{O}-\mathrm{K}_{2} \mathrm{O}-\mathrm{CaO}$ diagrams for these Y-3 volcanic rocks, as well as for hydrothermally altered glacial sediments from the upper part of the Y-3 drill core. All of the rocks are alkali rich (especially potassium) and calcium poor. As such, the dominance of calcium-bearing hydrothermal minerals in the lower rhyolitic volcanic section of Y-3 would appear to be due to the waters that deposited the miner- 
als. In fact, a comparison of chemical analyses of water from the Y-3 drill hole and from nearby Ojo Caliente Hot Spring (table 1) suggests that calcium, along with potassium, is probably lost during adiabatic cooling of an ascending boiling water, whereas sodium remains unchanged after correcting for boiling (Bargar and others, 1973).

The silica geothermometer for Ojo Caliente Hot Spring water $\left(176^{\circ} \mathrm{C}\right)$ is in good agreement with the measured temperature $\left(174^{\circ} \mathrm{C}\right)$ for water from the $88-\mathrm{m}$ aquifer in drill hole Y-3 (table 1, column 2). Other geothermometer calculations in table 1 give temperatures that are too low for Y-3. Calculated geothermometers for the bottom-water (table 1, column 1) are significantly lower than the $196^{\circ} \mathrm{C}$ measurement at the bottom of the drill hole. At the time the Y-3 bottom water sample was collected, White and others (1975) concluded that the region below $80 \mathrm{~m}$ in the drill hole was influenced by downflow of cooler water from the upper part of the drill hole.

Fluid-inclusion homogenization temperatures were measured in quartz (48 fluid inclusions in 4 samples) and fluorite (47 fluid inclusions in 3 samples) crystals from the Y-3 drill core. Most of the liquid-rich fluid inclusions appear to be secondary(?) or pseudosecondary and have homogenization temperatures that plot very close to the present-day measured temperature curve (fig. 23). One homogenization temperature measurement of $313.5^{\circ} \mathrm{C}$ at $45.8 \mathrm{~m}$ was not reported in figure 23 because the value obviously was too high owing to necking-down of the fluid inclusion by precipitation of later silica (Roedder, 1984). Similarly a few other small, irregular fluid inclusions, some with "tails," may give erroneous (either too high or too low) homogenization temperatures. Probably the most reliable homogeniza-

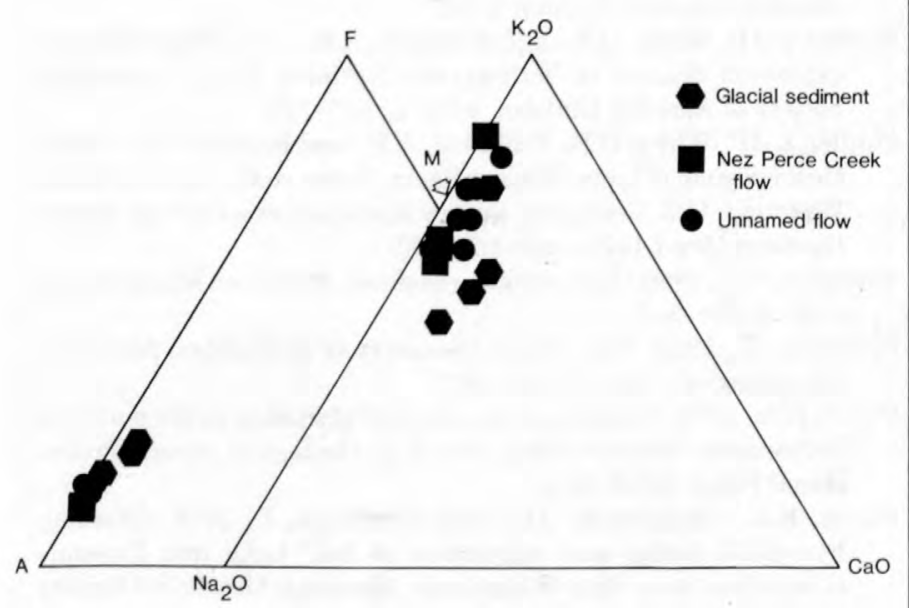

FIGURE 22.-A-F-M and $\mathrm{Na}_{2} \mathrm{O}-\mathrm{K}_{2} \mathrm{O}-\mathrm{CaO}$ ternary diagrams for altered volcanic rocks and glacial sediments from drill core Y-3.

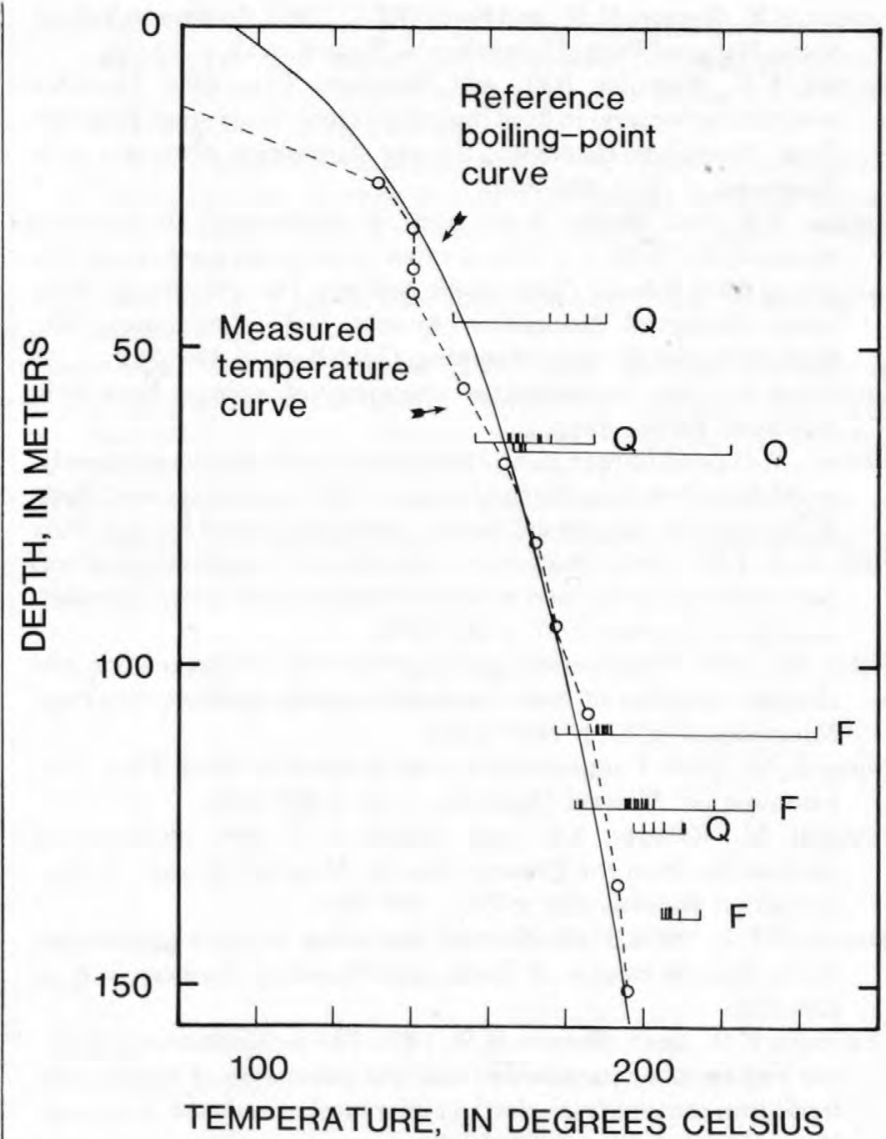

Figure 23.-Plot of fluid-inclusion homogenization temperatures in quartz $(\mathrm{Q})$ and fluorite $(\mathrm{F})$ crystals from seven samples in drill core Y-3. Horizontal line segments give range of homogenization temperature measurements, which are shown as short vertical tick marks.

tion temperatures shown in figure 23 are the clustered measurements, which usually plot less than about $20-40^{\circ} \mathrm{C}$ from the measured temperature curve. From these data we infer that the temperature of the water that deposited the quartz and fluorite crystals studied was a little warmer than the temperatures measured during drilling.

\section{REFERENCES CITED}

Alberti, A., 1975, Sodium-rich dachiardite from Alpe de Siusi, Italy: Contributions to Mineralogy and Petrology, v. 49, p. 63-66.

Alietti, A., 1972, Polymorphism and crystal-chemistry of heulandites and clinoptilolites: American Mineralogist, v. 57, p. 1448-1462.

Bargar, K.E., and Beeson, M.H., 1981, Hydrothermal alteration in research drill hole Y-2, Lower Geyser Basin, Yellowstone National Park, Wyoming: American Mineralogist, v. 66, p. 473-490. -1984, Hydrothermal alteration in research drill hole Y-6, Upper Firehole River, Yellowstone National Park, Wyoming: U.S. Geological Survey Professional Paper 1054-B, 24 p.

Bargar, K.E., Beeson, M.H., Fournier, R.O., and Muffler, L.J.P., 1973 , Present-day deposition of lepidolite from thermal waters in Yellowstone National Park: American Mineralogist, v̀. 58, p. 901-904 
Bargar, K.E., Beeson, M.H., and Keith, T.E.C., 1981, Zeolites in Yellowstone National Park: Mineralogical Record, v. 12, p. 29-38.

Bargar, K.E., Fournier, R.O., and Theodore, T.G., 1984, Particles resembling bacteria in fluid inclusions from Yellowstone National Park, Wyoming: Geological Society of America Abstracts with Programs, v. 16, p. 436-437.

Bargar, K.E., and Muffler, L.J.P., 1982, Hydrothermal alteration in research drill hole Y-11 from a vapor- dominated geothermal system at Mud Volcano, Yellowstone National Park, Wyoming: Wyoming Geological Association Annual Field Conference, 33d, Mammoth Hot Springs, Wyoming, Guidebook, p. 139-152.

Barrer, R.M., 1982, Hydrothermal chemistry of zeolites: New York, Academic Press, $360 \mathrm{p}$.

Beeson, M.H., and Bargar, K.E., 1984, Major and trace element analyses of drill cores from thermal areas in Yellowstone National Park, Wyoming: U.S. Geological Survey Open-File Report 84-373, 40 p.

Birkeland, P.W., 1969, Quaternary paleoclimatic implications of soil clay mineral distribution in Sierra Nevada-Great Basin Transect: Journal of Geology, v. 77, p. 289-302.

Boles, J.R., 1972, Composition, optical properties, cell dimensions, and thermal stability of some heulandite-group zeolites: American Mineralogist, v. 57, p. 1463-1493.

Bonardi, M., 1979, Composition of type dachiardite from Elba: a reexamination: Mineral Magazine, v. 43, p. 548-549.

Bonardi, M., Roberts, A.C., and Sabina, A.P., 1981, Sodium-rich dachiardite from the Francon Quarry, Montreal Island, Quebec: Canadian Mineralogist, v. 19, p. 285-289.

Browne, P.R.L., 1978, Hydrothermal alteration in active geothermal fields: Annual Review of Earth and Planetary Sciences, v. 6, p. 229-250.

Cawthorn, R.G., and Collerson, K.D., 1974, The recalculation of pyroxene end-member parameters and the estimation of ferrous and ferric iron content from electron microprobe analyses: American Mineralogist, v. 59, p. 1203-1208.

Christiansen, R.L., and Blank, H.R., Jr., 1972, Volcanic stratigraphy of the Quaternary rhyolite-plateau in Yellowstone National Park: U.S. Geological Survey Professional Paper 729-B, 18 p. -1974, Geologic map of the Madison Junction quadrangle, Yellowstone National Park, Wyoming: U.S. Geological Survey Geologic Quadrangle Map GQ-1190, scale 1:62,500.

Deer, W.A., Howie, R.A., and Zussman, J., 1962, Rock-forming minerals: Vol. 3 sheet silicates: London, Longmans, 270 p. -1963, Rock-forming minerals: Vol. 4 framework silicates: New York, John Wiley, $435 \mathrm{p}$.

-1966, An introduction to the rock-forming minerals: London, Longmans, $528 \mathrm{p}$.

Eberlein, G.D., Erd, R.C., Weber, F., and Beatty, L.B., 1971, New occurrence of yugawaralite from the Chena Hot Springs area, Alaska: American Mineralogist, v. 56, p. 1699-1717.

Fenner, C.N., 1936, Bore-hole investigations in Yellowstone Park: Journal of Geology, v. 44, p. 225-315.

Fieldes, M., and Perrott, K.W., 1966, The nature of allophane in soils: Part 3. Rapid field and laboratory test for allophane: New Zealand Journal of Science, v. 9, p. 623-629.

Fournier, R.O., 1981, Application of water geochemistry to geothermal exploration and reservoir engineering, in Rybach, L., and Muffler, L.J.P., eds., Geothermal Systems: Principles and Case Histories: New York, John Wiley, p. 109-143.

Grim, R.E., 1968, Clay mineralogy: San Francisco, McGraw-Hill, $596 \mathrm{p}$.

Holland, H.D., 1967, Gangue minerals in hydrothermal deposits, in Barnes, H.L., ed., Geochemistry of Hydrothermal Ore Deposits: New York, Holt, Rinehart \& Winston, p. 382-436.
Honda, S., and Muffler, L.J.P., 1970, Hydrothermal alteration in core from research drill hole Y-1, Upper Geyser Basin, Yellowstone National Park, Wyoming. American Mineralogist, v. 55, p. 1714-1737.

Hower, J., 1981, X-ray diffraction identification of mixed-layer clay minerals: Mineralogical Association of Canada Short Course, p. 39-59.

Juan, V.C., Vouh, C.-C., and Lo, H.-J., 1970, The dehydration reaction of natural truscottite: Proceedings of the Geological Society of China, v. 13, p. 34-40.

Keith, T.E.C., Beeson, M.H., and White, D.E., 1978a, Hydrothermal minerals in U.S. Geological Survey research drill hole Y-13, Yellowstone National Park, Wyoming [abs.]: Geological Society of America Abstracts with Programs, v. 10, p. 432-433.

Keith, T.E.C., and Muffler, L.J.P., 1978, Minerals produced during cooling and hydrothermal alteration of ash flow tuff from Yellowstone drill hole Y-5: Journal of Volcanology and Geothermal Research, v. 3, p. 373-402.

Keith, T.E.C., Thompson, J.M., and Mays, R.E., 1983, Selective concentration of cesium in analcime during hydrothermal alteration, Yellowstone National Park, Wyoming: Geochimica et Cosmochimica Acta, v. 47, p. 795-804.

Keith, T.E.C., White, D.E., and Beeson, M.H., 1978b, Hydrothermal alteration and self-sealing in Y-7 and Y-8 drill holes in northern part of Upper Geyser Basin, Yellowstone National Park, Wyoming: U.S. Geological Survey Professional Paper 1054-A, 26 p.

Knauss, K.G., and Beiriger, W.J., 1984, Dachiardite formation by hydrothermal alteration of a devitrified high silica rhyolite [abs.] Geological Society of America Abstracts with Programs, v. 16, p. 561.

Leeman, W.P., and Phelps, D.W., 1981, Partitioning of rare earths and other trace elements between sanidine and coexisting volcanic glass: Journal of Geophysical Research, v. 86, no. B11, p. 1019310199.

McCulloh, T.H., Frizzell, V.A., Jr., Stewart, R.J., and Barnes, I., 1981, Precipitation of laumontite with quartz, thenardite, and gypsum at Sespe Hot Springs, Western Transverse Ranges, California: Clays and Clay Minerals, v. 29, p. 353-364.

Minato, H., and Kato, A., 1967, Truscottite from the Toi Mine, Shizuoka prefecture: Mineralogical Journal, v. 5, p. 144-156.

Muffler, L.J.P., and Bargar, K.E., 1974, Hydrothermal alteration of rhyolitic ash-flow tuff in the vapor-dominated geothermal system at Mud Volcano, Yellowstone National Park, U.S.A. [abs.]: International Symposium on Water-Rock Interaction, Prague, Czechoslovakia, Abstract Volume, p. 52.

Muffler, L.J.P., White, D.E., and Truesdell, A.H., 1971, Hydrothermal explosion craters in Yellowstone National Park: Geological Society of America Bulletin, v. 82, p. 723-740.

Muffler, L.J.P., White, D.E., Truesdell, A.H., and Fournier, R.O., 1982 , Geologic map of Lower Geyser Basin, Yellowstone National Park, Wyoming: U.S. Geological Survey Miscellaneous Geologic Investigations Map I-1373, scale 1:24,000.

Mumpton, F.A., 1960, Clinoptilolite redefined: American Mineralogist, v. 45 , p. $351-369$.

Passaglia, E., 1970, The crystal chemistry of chabazites: American Mineralogist, v. 55, p. 1278-1301.

Pierce, K.L., 1979, History and dynamics of glaciation in the northern Yellowstone National Park area: U.S. Geological Survey Professional Paper 729-F, 90 p.

Pierce, K.L., Obradovich, J.D., and Friedman, I., 1976, Obsidian hydration dating and correlation of Bull Lake and Pinedale Glaciations near West Yellowstone, Montana: Geological Society of America Bulletin, v. 87, p. 703-710. 
Pongiluppi, D., 1977, A new occurrence of yugawaralite at Osilo, Sardinia: Canadian Mineralogist, v. 15, p. 113-114.

Roedder, E., 1984, Fluid inclusions: v. 12 of Reviews in Mineralogy: Mineralogical Society of America, $644 \mathrm{p}$.

Schoen, R., White, D.E., and Hemley, J.J., 1974, Argillization by descending acid at Steamboat Springs, Nevada: Clays and Clay Minerals, v. 22, p. 1-22.

Sheppard, R.A., and Gude, A.J., 3d, 1969, Diagenesis of tuffs in the Barstow Formation, Mud Hills, San Bernardino County, California: U.S. Geological Survey Professional Paper 634, 35 p.

Silberman, M.L., White, D.E., Keith, T.E.C., and Dockter, R.D., 1979 , Duration of hydrothermal activity at Steamboat Springs, Nevada, from ages of spatially associated volcanic rocks: U.S. Geological Survey Professional Paper 458-D, 14 p.

Thompson, J.M., and Yadav, S., 1979, Chemical analyses of waters from geysers, hot springs and pools in Yellowstone National Park, Wyoming from 1974 to 1978: U.S. Geological Survey Open-File Report 79-704, 49 p.
Waldrop, H.A., and Pierce, K.L., 1975, Surficial geologic map of the Madison Junction quadrangle, Yellowstone National Park, Wyoming: U.S. Geological Survey Miscellaneous Geologic Investigations Map I-651, scale 1:62,500.

White, D.E., Fournier, R.O., Muffler, L.J.P., and Truesdell, A.H., 1975, Physical results of research drilling in thermal areas of Yellowstone National Park, Wyoming: U.S. Geological Survey Professional Paper 892, $70 \mathrm{p}$.

Wise, W.S., 1978, Yugawaralite from Bombay, India: Mineralogical Record, v. 5, p. 296.

Wise, W.S., and Tschernich, R.W., 1978, Dachiardite-bearing assemblages in the Pacific Northwest, in Sand, L.B., and Mumpton, F.A., eds., Natural zeolites: occurrence, properties, use: New York, Pergamon Press, p. 105-111.

Zeng, Y., and Liou, J.G., 1982, Experimental investigation of yugawaralite-wairakite equilibrium: American Mineralogist, v. 67, p. 937-943. 


